\title{
3D structure and formation of hydrothermal vent complexes at the Paleocene-Eocene transition, the Møre Basin, mid-Norwegian margin
}

\author{
Sigurd Kjoberg ${ }^{1}$, Tobias Schmiedel ${ }^{2}$, Sverre Planke ${ }^{3}$, Henrik H. Svensen ${ }^{1}$, John M. Millett ${ }^{4}$, Dougal A. \\ Jerram $^{5}$, Olivier Galland ${ }^{2}$, Isabelle Lecomte ${ }^{6}$, Nick Schofield ${ }^{7}$, Øystein T. Haug ${ }^{2}$, and Andreas Helsem ${ }^{8}$
}

\begin{abstract}
The mid-Norwegian margin is regarded as an example of a volcanic-rifted margin formed prior to and during the Paleogene breakup of the northeast Atlantic. The area is characterized by the presence of voluminous basaltic complexes such as extrusive lava and lava delta sequences, intrusive sills and dikes, and hydrothermal vent complexes. We have developed a detailed 3D seismic analysis of fluid- and gas-induced hydrothermal vent complexes in a $310 \mathrm{~km}^{2}$ area in the Møre Basin, offshore Norway. We find that formation of hydrothermal vent complexes is accommodated by deformation of the host rock when sills are emplaced. Fluids are generated by metamorphic reactions and pore-fluid expansion around sills and are focused around sill tips due to buoyancy. Hydrothermal vent complexes are associated with doming of the overlying strata, leading to the formation of draping mounds above the vent contemporary surface. The morphological characteristics of the upper part and the underlying feeder structure (conduit zone) are imaged and studied in 3D seismic data. Well data indicate that the complexes formed during the early Eocene, linking their formation to the time of the Paleocene-Eocene thermal maximum at c. $56 \mathrm{Ma}$. The well data further suggest that the hydrothermal vent complexes were active for a considerable time period, corresponding to a c. $100 \mathrm{~m}$ thick transition zone unit with primary Apectodinium augustum and redeposited very mature Cretaceous and Jurassic palynomorphs. The newly derived understanding of age, structure, and formation of hydrothermal vent complexes in the Møre Basin contributes to the general understanding of the igneous plumbing system in volcanic basins and their implications for the paleoclimate and petroleum systems.
\end{abstract}

\section{Introduction}

At the mid-Norwegian margin, the Paleocene-Eocene interval represents the time period of the early northeast Atlantic rifting and continental breakup (Gibb and Kanaris-Sotiriou, 1988; Bell and Butcher, 2002). Evidence for volcanic activity in sedimentary basins is found along the entire European northeast Atlantic margin (Doré et al., 1999). Volcanic processes and deposits may have significant impact on the structural and geodynamic development of the rifted margin and associated sedimentary basins, i.e., the Karoo Basin, the Rockall Basin, the Faroe-Shetland Basin, and the Neuquén Basin (Smallwood and Maresh, 2002; Svensen et al., 2012; Magee et al.,
2014; Schofield et al., 2017). The Møre Basin study area is located beneath the outer shelf and slope region offshore mid-Norway, and it shows classic examples of how volcanic activity and igneous intrusions within sedimentary strata may impact the basin structure (Skogseid et al., 1992; Brekke, 2000). The short- and long-term impacts include deformation, differential compaction, uplift, heating of host rock and pore fluids, metamorphism, and the formation of hydrothermal vent complexes (HTVCs).

The distribution and nature of volcanic intrusions and associated hydrothermal vent complexes represent key elements in basin evolution, and therefore it is important to better constrain the age of the main volcanic

\footnotetext{
${ }^{1}$ The University of Oslo, The Centre for Earth Evolution and Dynamics (CEED), Oslo, Norway. E-mail: sigurdkj@geo.uio.no; hensven@geo.uio.no.

${ }^{2}$ The University of Oslo, Physics of Geological Processes (PGP), Oslo, Norway. E-mail: tobias.schmiedel@geo.uio.no; olivier.galland@geo.uio.no; o.t.haug@geo.uio.no.

${ }^{3}$ The University of Oslo, The Centre for Earth Evolution and Dynamics (CEED), Oslo, Norway, and Volcanic Basin Petroleum Research (VBPR), Oslo, Norway. E-mail: planke@vbpr.no.

${ }^{4}$ Volcanic Basin Petroleum Research (VBPR), Oslo, Norway and The University of Aberdeen, Aberdeen, UK. E-mail: john.millett@vbpr.no.

${ }^{5}$ The University of Oslo, The Centre for Earth Evolution and Dynamics (CEED), Oslo, Norway and DougalEarth, Solihull, UK. E-mail: dougal@ dougalearth.com.

${ }^{6}$ NORSAR, Kjeller, Norway and The University of Bergen, Bergen, Norway. E-mail: isabelle.lecomte@uib.no.

${ }^{7}$ The University of Aberdeen, Aberdeen, UK. E-mail: n.schofield@abdn.ac.uk.

${ }^{8}$ Statoil, Stavanger, Norway. E-mail: anhell@statoil.com.

Manuscript received by the Editor 28 September 2016; revised manuscript received 25 January 2017; published online 9 May 2017. This paper appears in Interpretation, Vol. 5, No. 3 (August 2017); p. SK65-SK81, 15 FIGS., 2 TABLES.

http://dx.doi.org/10.1190/INT-2016-0159.1. @ 2017 Society of Exploration Geophysicists and American Association of Petroleum Geologists. All rights reserved.
} 
episode and the coherent venting processes. In addition, the venting process has been related to greenhouse gas expulsion to the atmosphere, thereby providing a link to the transient climatic shift during the Paleocene-Eocene Thermal Maximum (PETM) (Svensen et al., 2004; Berndt et al., 2016). The climatic records during this period are well documented from several sections worldwide (Zachos et al., 2001; Zachos et al., 2008), and recent results show that the only drilled HTVC in the Vøring Basin (borehole 6607/12-1) formed during the PETM plateau, thereby demonstrating a relationship between the long duration of the PETM and the gas venting (Frieling et al., 2016). Similar kilometer-scale hydrothermal vent structures have been described elsewhere in seismic data (Hansen et al., 2005; Planke et al., 2005; Grove, 2013; Berndt et al., 2016) and in outcrops (Svensen et al., 2006) in several basins. These vent structures all share structural similarities, including complete brecciation, fluidization, and inward-dipping reflections. However, the upper parts of these vents imaged on seismic data often exhibit distinct structural features (eye, crater, and dome shapes). The mechanisms leading to different structures are currently unknown. In addition, the structural features observed in seismic data differ from those described in field and outcrop studies. It is not clear whether the differences between seismic features and geologic observations are real structural differences or the result of artifacts in the seismic images.

The aim of this study is to increase our understanding of the formation and age of hydrothermal venting in volcanic basins. This study is based on structural imaging and detailed mapping of morphological features in a 3D seismic survey acquired in the Møre Basin, together with well-log data and analyses. We further apply a new workflow to better constrain the complex structures of hydrothermal vent complexes on seismic images, using a combination of qualitative laboratory models and advanced seismic modeling. These results may help identify potential artifacts related to fluid and sediment remobilization in seismic images.

\section{Møre Basin geological setting}

The mid-Norwegian margin developed through a series of post-Caledonian rift phases that culminated with the onset of seafloor spreading ca. $56 \mathrm{Ma}$ in the Norwegian-Greenland Sea (Mosar et al., 2002). The Møre and Vøring margin segments, each between 400 and $500 \mathrm{~km}$ long, are separated by the Jan Mayen Fracture Zone (Figure 1; Faleide et al., 2008). The deep Møre and Vøring Basins formed during Late Jurassic-Early Cretaceous rifting episodes (Figure 1). The basins are characterized by thick Cretaceous sedimentary accumulations and can in places reach up to $13 \mathrm{~km}$, of which 8-9 km comprises the Cretaceous succession (Gernigon et al., 2003). Continental breakup was accompanied by large-scale igneous activity, forming kilometer-thick basaltic complexes on both sides of the continent-ocean boundary (Brekke, 2000). At the same time, extensive igneous sheet intrusions were emplaced in the Møre Basin, and hundreds of hydrothermal vent complexes were

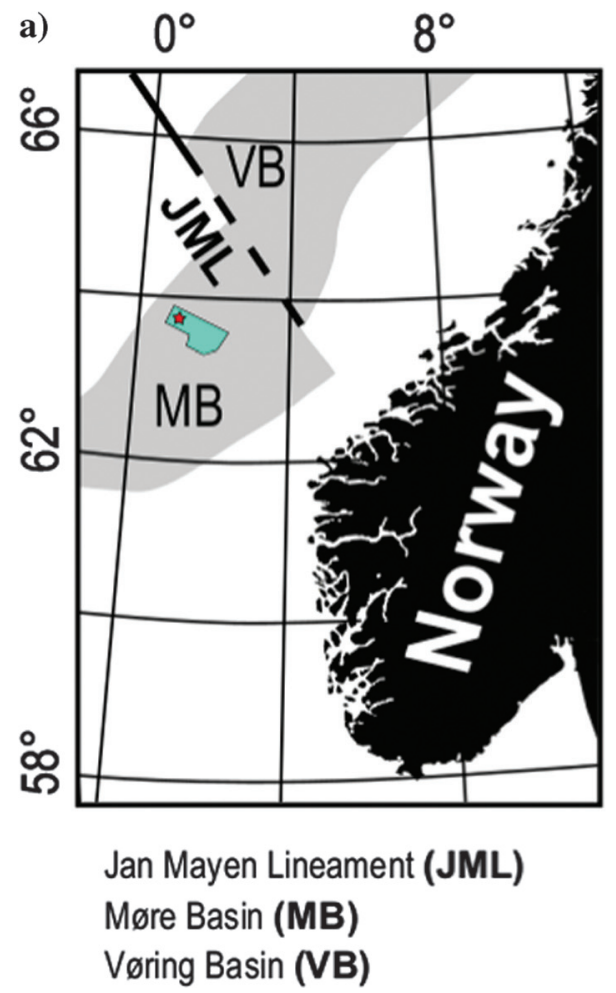

b)

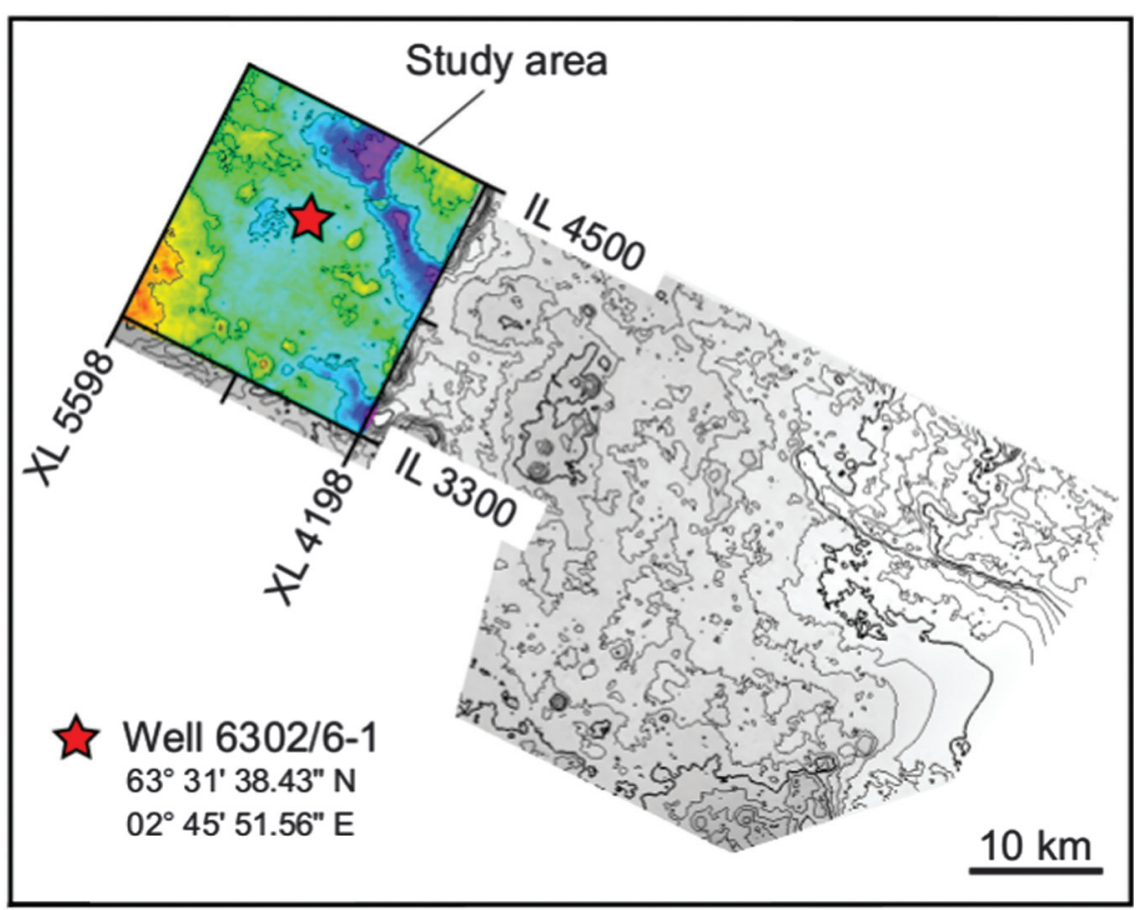

Figure 1. Location map showing the study area in the Møre Basin on the mid-Norwegian margin. The 3D survey is approximately $2100 \mathrm{~km}^{2}$, and the interpreted study area is approximately $310 \mathrm{~km}^{2}$. 
formed by pressure increase and devolatilization in the contact aureoles around the sills (Planke et al., 2005, 2015; Svensen et al., 2004; Svensen and Jamtveit, 2010; Frieling et al., 2015). The Møre Basin subsequently subsided, leading to deposits of marine mud and ooze, and finally thick sequences of glacially derived sediments and slide material (Faleide et al., 2008).

\section{Stratigraphy}

The seismic well-tie in the Paleogene and Neogene (Cenozoic) successions is confident (Figure 2). However, the sequences less than $4.4 \mathrm{~s}$ two way traveltime (TWT) of late Cretaceous age are difficult to tie because of imaging problems and lack of well data. The stratigraphy includes five formations and is described from the oldest to youngest unit. In the study area, the lowermost interpreted formation is the Springar Formation. It consists of predominantly grayish-green claystones interbedded with stringers of carbonates and sandstone (Dalland et al., 1988). Limestone beds exceeding $10 \mathrm{~m}$ in thickness interbedded with shale are encountered at an interval from 4076 to $4140 \mathrm{~m}$ (measured depth [MD]). The Springar Formation is overlain by the Paleogene Tang Formation, which is characterized by dark-gray to brown claystone with minor sandstone and limestone (Dalland et al., 1988). The lithology of the lowermost part and the transitional zone into the Springar Formation is interpreted as the Danian sandstone reservoir of the Tulipan discovery. These sandstone layers are typically $1-$ $7 \mathrm{~m}$ thick and interbedded with siltstone and claystone in the depth range between 3901 and $4000 \mathrm{~m}$ (MD).

The Tare Formation is defined by dark-gray, green, or brown claystones with some thin sandstone stringers and a variable content of tuffaceous material. The tuff content is highest toward the basal section of the formation, with increasing volume in the lowermost Eocene sediments. The Tare Formation is overlain by the late Eocene to middle Miocene Brygge Formation, which is part of the Hordaland group (Deagan and Scull, 1977; Dalland et al., 1988). The Brygge Formation consists mainly of

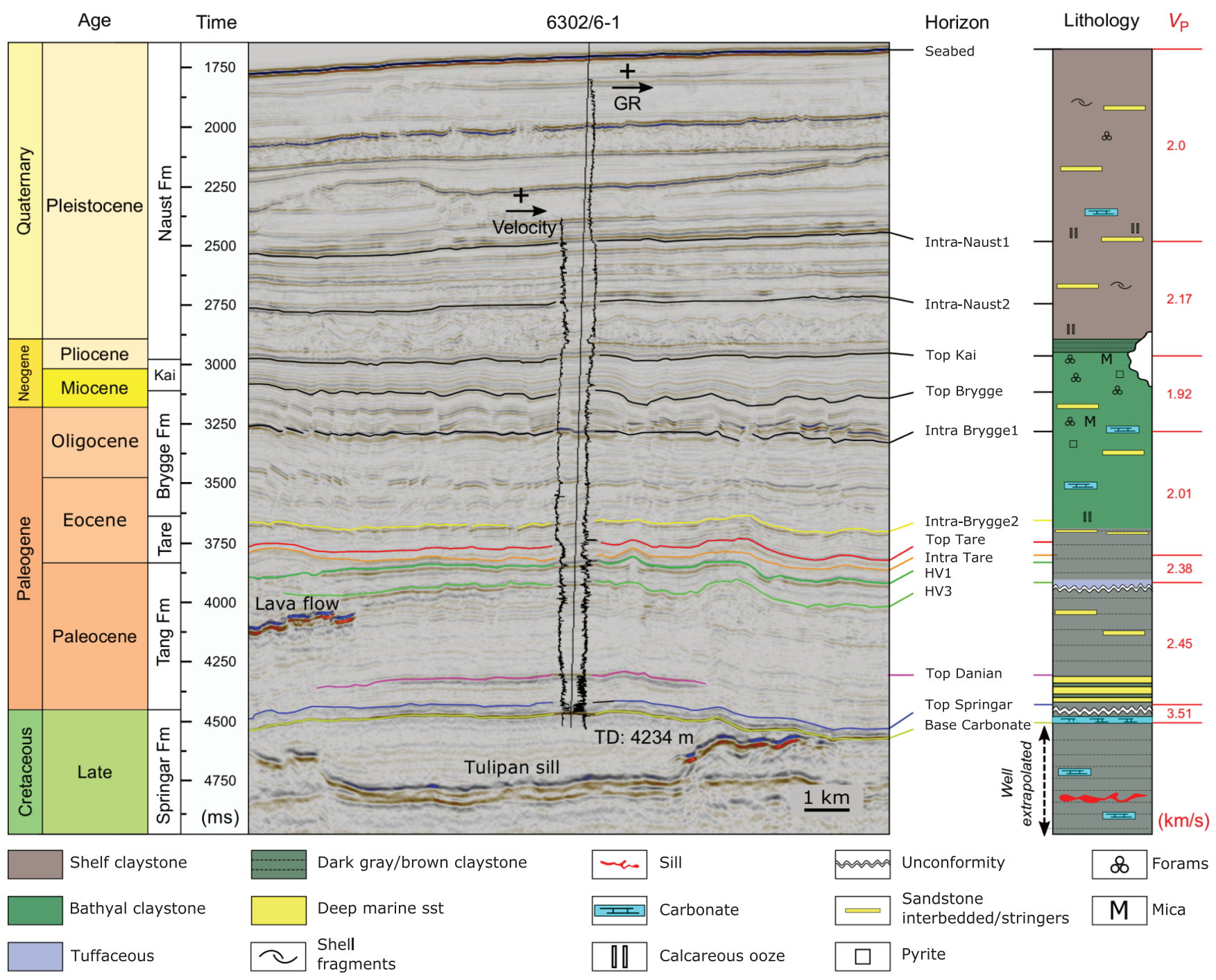

Figure 2. Summary diagram showing the key-interpreted horizons and synthesis of well 6302/6-1 lithostratigraphic data. See Figure 1 for the profile location. 
claystone, interbeds of sandstone, and biosiliceous ooze (Hjelstuen et al., 1997). The two uppermost formations in the study area are the Lower Miocene to recent Nordland group that is subdivided into the Kai Formation and the upper Pliocene Naust Formation (Dalland et al., 1988). The Kai Formation consists of alternating claystone, siltstone, and sandstone with interbedded limestone, and the Naust Formation mainly comprises claystone and siltstone.

\section{Formation and source of hydrothermal vent complexes}

The formation of hydrothermal complexes (HTVCs) requires that fluid pressure within contact aureoles overcomes the rock strength and the lithostatic pressure. Instantaneous overpressure release occurs if the pressure buildup is faster than the pressure release and seepage in the host rock. Jamtveit et al. (2004) and Nermoen et al. (2010) propose a model in which the venting mechanism is based on boiling and expansion of pore water as the cause for pressure buildup. If the fluids generated are greater than allowable through Darcy flow, a critical state is reached and venting can occur (Jamtveit et al., 2004; Nermoen et al., 2010). Lithologic information from the Møre Basin shows that the host rock consists of primarily mudstone, claystone, and sandstone at the HTVC interval. Mudstone heating can result in clay mineral dehydration and organic matter breakdown to $\mathrm{CO}_{2}$ and $\mathrm{CH}_{4}$, contributing to overpressure generation (see Svensen et al., 2004, 2007; Aarnes et al., 2010). The fluid generation is critically dependent on the heat transfer from the sill and is a function of host rock properties, sill thickness and temperature, and the geothermal gradient (Aarnes et al., 2010; Grapes, 2010).

Fluids generated in contact aureoles have low densities and greater buoyancy compared with the pore fluids in the sedimentary rocks. The presence of lighter components, such as methane, may dissolve in the fluids or migrate as a gas phase during the formation of HTVCs (Svensen and Jamtveit, 2010; Wang and Manga, 2015). The volume of these carbon-bearing gases depends on the total amount of organic carbon in the host rock (Whitaker, 1986).

\section{Data and methods \\ Seismic and well data}

The seismic data used in this paper consist of a subsection $\left(310 \mathrm{~km}^{2}\right)$ of the ST0105 (Tulipan) 3D survey $(2100 \mathrm{~km})$, collected and processed in connection with the PL251 license in 2005. The survey is situated in the western part of the Møre Basin, offshore mid-Norway (Figure 1). The data are 3D time migrated, and the overall quality is regarded as very good. The main frequency spectrum of the data is approximately $20-40 \mathrm{~Hz}(3.7-$ $4.5 \mathrm{~s}$ TWT). This implies a dominant wavelength of $30-50 \mathrm{~m}$, corresponding to a vertical seismic resolution of approximately $10 \mathrm{~m}(\delta h=\lambda / 4$ : one quarter of the dominant wavelet). The data are regarded as zero phase and displayed so that white/blue (depending on color scheme) denotes an increase in acoustic impedance.

Borehole check-shot and conventional wireline log data from the Tulipan well (6302/6-1; Figure 2) show that velocities vary from approximately $2000 \mathrm{~m} / \mathrm{s}$ at the seafloor to more than $3000 \mathrm{~m} / \mathrm{s}$ at the base of the interpretation interval. Finally, 6302/6-1 borehole stratigraphy, petrography, and biostratigraphy reports were made available from Statoil. Results from these reports are summarized in Figure 2.

\section{Seismic interpretation}

In total, 14 seismic horizons were interpreted regionally in the study area based on the seismic well tie to 6302/6-1 (Figure 2). The interpretation focused on the Paleocene and Eocene sequences, in particular, the Intra Brygge 2, Top Tare, Intra Tare, HV1, and HV3 horizons. These horizons are well-defined, continuous events in the study area (Figure 2) and are used to define the upper part of the hydrothermal vent complexes. In addition, sills and lava flows were interpreted using the approach of Planke et al. (2015).

The upper part of each vent complex is defined as a domed region with down-lapping internal reflections on HV1. In 3D, the dome structures display an ellipsoidal geometry. Thus, the lengths of the minor and major axes could be determined. The conduit height is defined as the depth between the termination of the interpreted underlying feeder sill and the HV1 surface. The depth to the sill is not always clearly defined because a vent complex may have originated from deeper, poorly imaged sills.

\section{Sandbox and seismic modeling}

One of the main challenges regarding interpretation of seismic images and complex geologic structures is to avoid potential pitfalls and misinterpretations due to, e.g., seismic artifacts, illumination, and resolution issues. To overcome this challenge, new seismic modeling appears as a valuable tool to separate the real structure from a seismic artifact (Lecomte et al., 2015).

The principle of seismic modeling is to use geometric and attribute input parameters to produce a synthetic seismic image. The comparison between the input geometry and the resulting image is a key aspect of deciphering between the real structures and the artifacts on seismic data. As geometric input parameter for hydrothermal vent complexes, a laboratory experiment of fluid overpressure structures in granular and unconsolidated media has been undertaken. These experiments proved very useful to unravel the dynamics of venting, with applications to pockmarks, mud volcanoes, hydrothermal vent complexes, and kimberlite pipes (Nermoen et al., 2010; Haug et al., 2013; Galland et al., 2014). Importantly, the structures simulated in the laboratory are comparable in geometry with the structures observed in the field, although the laboratory models have to be upscaled.

The sandbox experiment setup consisted of a vertically orientated, air-filled Hele-Shaw cell measuring $60 \times 60 \mathrm{~cm}$ (Nermoen et al., 2010; Haug et al., 2013). 
The cell is sealed at the bottom and the vertical sides, whereas the top part of the cell remains open. Each experiment was prepared by slowly pouring alternating olivine sand and quartz sand through a funnel, from the top of the cell to a desired filling height. Overpressurized air from a constant supply was injected into the sand through an inlet placed within the bed. The flow velocities in the experiment were regarded as constant because the air supply was induced at a uniform pressure throughout the experiments. Digital images during the experiment were captured at seven frames per second using a high-resolution camera.

The most representative picture obtained during the sandbox experiment served as a target model for the synthetic seismic modeling. The target model was implemented into the modeling software (SeisRox) as a 2D layer model. The sand makes up the basic geometry of the model and it is defined by the different layers related to the sedimentary sequences and the coherent change in elastic values $\left(V_{\mathrm{P}}\right.$ and $V_{\mathrm{S}}$ velocities). The following assumptions were further implemented:

1) The horizontal and vertical sizes of the background picture are defined as 1800 and $850 \mathrm{~m}$, respectively, based on dimension analysis done during seismic interpretation.

2) Velocity data available from sonic logs at the HTVC ranges $V_{\mathrm{P}}$ from 2000 to $2500 \mathrm{~m} / \mathrm{s}$ and $V_{\mathrm{S}}$ from 1100 to $1800 \mathrm{~m} / \mathrm{s}$, increasing with depth.

3) Two sets of velocities properties $\left(V_{\mathrm{P}}\right.$ and $\left.V_{\mathrm{S}}\right)$ were implemented to create the impedance/reflectivity model. These values range $V_{\mathrm{P}}$ between 2000 and $2300 \mathrm{~m} / \mathrm{s}$ and $V_{\mathrm{S}}$ between 1200 and $1300 \mathrm{~m} / \mathrm{s}$.

4) Density in the model varies from 2.0 to $2.2 \mathrm{~g} / \mathrm{cm}^{3}$.

5) The seismic properties within each zone are homogeneous and identical throughout the sequence, with no internal reflections.

6) Seismic modeling of $20 \mathrm{~Hz}$, corresponding to the HTVC interval. display local transgressive segments. Three sills have been mapped and picked as separate horizons. The lowermost sill is difficult to map with confidence, due to the acoustic masking of the overlying intrusions. The Tulipan sill is a saucer-shaped intrusion and it is easily recognized in the seismic section. Figure 2 shows that the Tulipan sill is forcing a dome-shaped morphology of the overlying Base Carbonate, Top Springar, and Top Danian horizons (Schmiedel et al., 2017). The Base Carbonate and Top Springar horizons are intersected and pierced by the transgressive segments of the sill, resulting in the most prominent HTVCs in the study area.

Figures 3 and 4 show the relationship between the underlying sills and the position of the different HTVCs. HV1 is the horizon of which the dome reflections are down-lapping. The spectral decomposition horizon in Figure 4 shows a clear relationship between the geometry of the underlying sills and the location of the vent complexes. Most of the vent complexes are seen along the outer margins of the Tulipan sill. The differences in rim elevation at the sill margin cause the conduit zones to shallow and deepen, depending on the sill position and elevation. Deeper situated vents are observed, in which the sills are less inclined.

\section{Seismic characteristics of the HTVC}

The recognition of the hydrothermal vent complexes is based primarily on interpretation of two horizons in the Paleogene sequence: HV1 and Top Tare (Figures 2 and 4). The reference horizon HV1 is defined by the seismic characteristics and well-defined geometry of the upper part of the vent complexes. In this study, 13 individual vent complexes have been identified and analyzed (Figures 4 and 5).

The upper part of the HTVC is seen in the seismic cross section as a dome down-lapping onto the HV1 paleosurface (Figures 5 and 6). The geometry and structural context display similarities to vent complexes described elsewhere on the Norwegian margin and in

\section{Results}

\section{Distribution of sills and vent complexes}

All HTVCs mapped in this study are related to underlying sills. Most of the vent complexes are associated with the saucer-shaped Tulipan sill located in the central part of the study area (Schmiedel et al., 2017). Due to the distinctive sill geometry, it is regarded as an important element in explaining the behavior, position, and structural development of the HTVCs. The extensive sill complex in the Tulipan 3D cube is interpreted based on the same method as the horizon interpretation (Planke et al., 2015). The sills are identified as high-amplitude reflections within the sedimentary strata and they

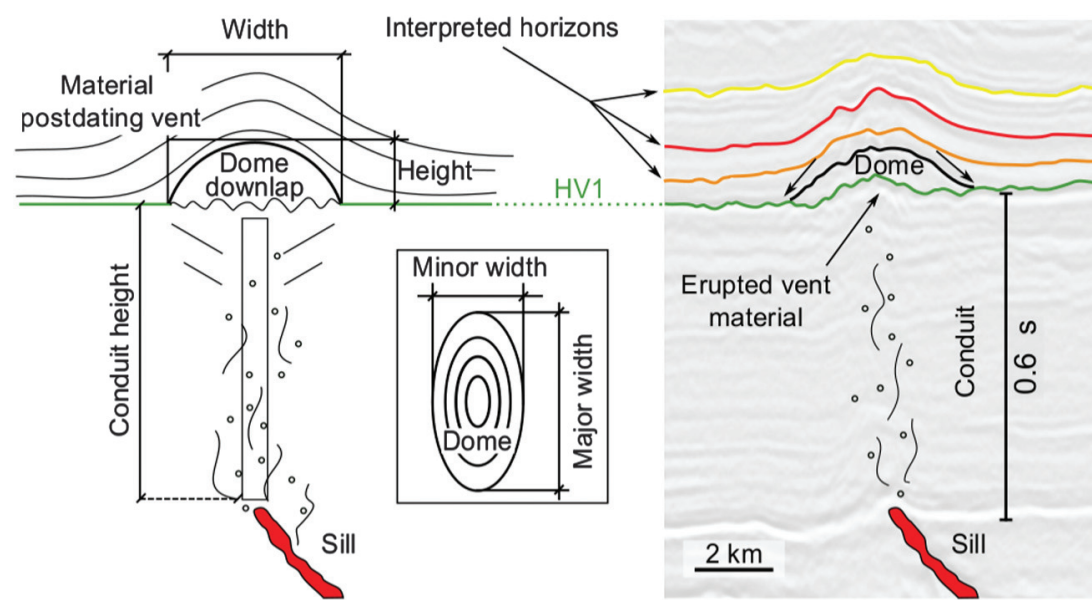

Figure 3. Schematic drawing together with seismic section showing the measurement criteria for the dome and conduit zone height and width of a hydrothermal vent complex. 
the Faroe Shetland Basin (Planke et al., 2005; Schofield et al., 2015). However, only vent complexes with domeshaped upper parts are present in the study area. Slight depressions are observed at the base of some structures, but the overall structure consists of a down-lapping dome, and no eye- or crater-shaped features are found as in the study of Planke et al. (2005). All of the vent complexes mapped in this study display a dome feature above HV1. Not all the domes down-lap onto HV1, but the majority do (11 out of 13), suggesting that this is a dominant behavior of the HTVCs in this part of the Møre Basin. Figure 6 illustrates domes on the HV1 horizon where the height of the structure is approximately $0.1 \mathrm{~s}$ (TWT), corresponding to $80-100 \mathrm{~m}$. The domes are used to give a qualitative measurement of the geometries of the upper part of the vent complexes (Table 1; Figure 7).
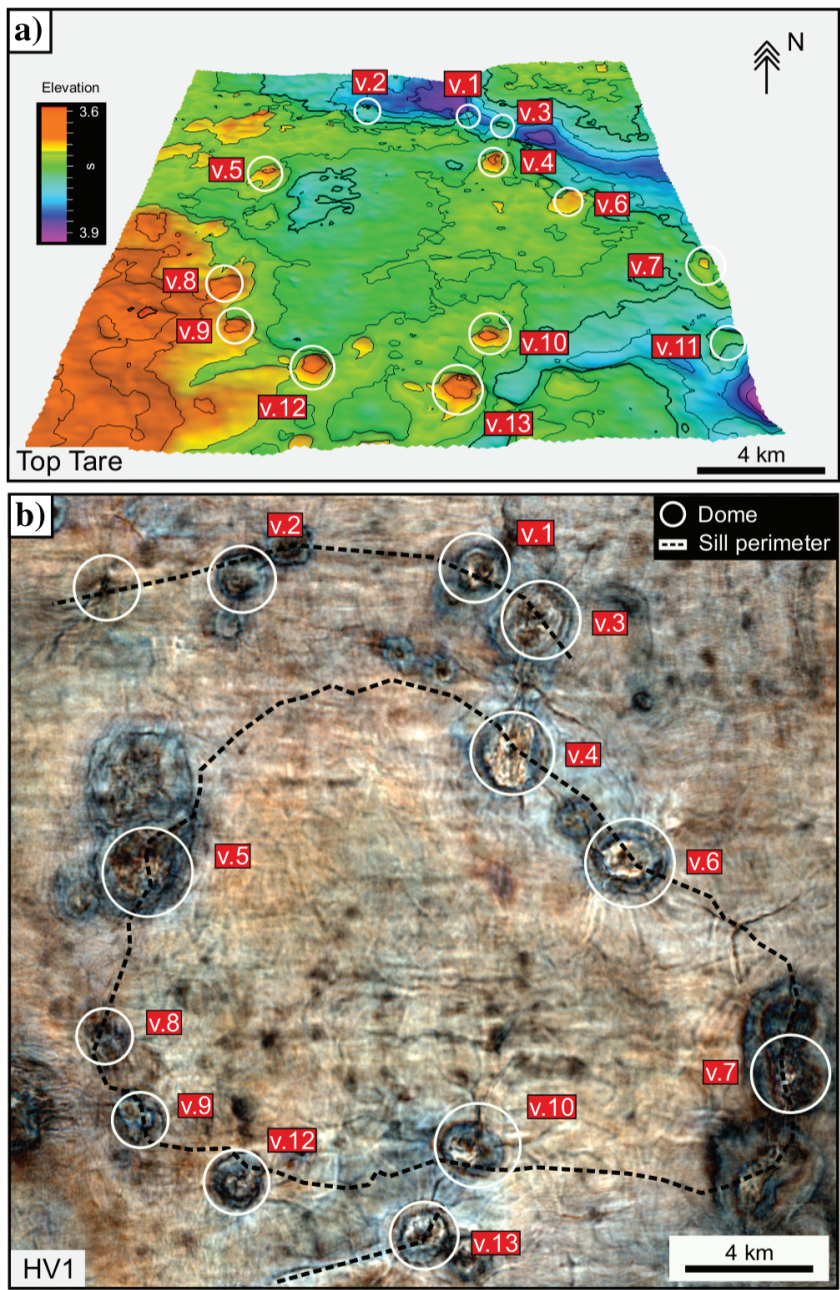

Figure 4. Dome geometry and morphology. (a) Time-structure map of the Top Tare (approximately intra-Eocene) horizon. White circles indicate the position of the dome structure of the HTVC, labeled v.1 to v.13. (b) Spectral decomposition of the HV1 paleosurface (red, $22 \mathrm{~Hz}$; green, $27 \mathrm{~Hz}$; and blue, $31 \mathrm{~Hz}$ ). The figure illustrates the relationship between the underlying Tulipan sill complex and the HTVCs seen on the HV1 surface.
The HTVC depth is essentially a measurement of the dome structural relief, made by defining a datum linked to the underlying HV1 horizon (Figure 3). Table 1 presents the sizes of the 13 individual HTVCs, showing sizes in the range of 70-120 m. The horizons above HV1 are characterized by a series of convex structures, which are described as draped mounded structures. The term "mounded structure" is used as a descriptive term in this paper to define the topographic relief of the dome above HV1 (Figure 5). To determinate the extent of these structures, the horizons were picked as a well-defined, high-amplitude, and continuous stratigraphic boundary, defined by the presence of the uppermost part of the convex-mounded reflections.

HTVCs are observed below mounding structures on the Top Tare horizon. They typically display sizes ranging from 600 to $2000 \mathrm{~m}$ in diameter and 70 to $120 \mathrm{~m}$ in height, with an elevated time ratio of $0.1 \mathrm{~s}$ (TWT). These mounded structures are exclusively observed in the Paleocene-Eocene transition zone and the lower part of the intra-Eocene interval. This interval is defined by a relatively abrupt decline in gamma and sonic response in well 6302/6-1 (Figure 2). In the stratigraphic completion log the interval is described as claystone with thin sandstone stringers with variable content of tuffaceous material. The sonic values in this interval could suggest a transition to more under-compacted and homogeneous clay-sandstone compositions beneath the tuff deposits.

\section{Vent conduit zone}

The vent conduit is interpreted as the disrupted, altered, or brecciated zone in which fluids and mobilized sediments migrated toward the paleosurface. The conduits are seen as disrupted reflections, resulting in a chaotic character of the originally stratified sedimentary host rocks. The 3D data show the conduits as vertical zones in the seismic data, where the amplitudes and reflections are distorted (Figures 3 and 5), consistent with earlier work in the basin and elsewhere (Heggland, 1998).

The conduit zones show variable morphologies. Some are conical and become thinner downwards toward the sill tip, whereas others display cylindrical morphologies. Not all the conduit zones display a traceable path from the dome down to their origin. In cases where the flow pattern is diverted by displaced fault blocks or magmatic bodies, the prediction of the sill and aureole origin is difficult. However, in general, the conduits do not appear to follow fault planes, and systematic fault cutting is not observed.

In the cases in which the conduit zones and the links to sills are uncertain, it might be a result of seismic imaging and detection problems. The overburden might also play a role in the interpretation. High-amplitude reflections may mask the underlying strata or create seismic artifacts by obscuring the underlying reflections (Schroot and Schüttenhelm, 2003). Reflections in the surrounding host strata are often seen to dip toward the conduit zone and the upper part of the HTVC. This feature is best observed in the seismic section crossing large HTVCs. 


\section{Sandbox modeling results}

Each of the experiments started with similar lithostatic stress conditions for the granular bedding in the Hele-Shaw cell (Figure 8). Compressed air from a pressurized tank was gradually imposed through the inlet by manually increasing the air flux using a valve. The pressure was increased slowly until the predefined supply pressure was reached, and the fluid-induced deformation of the matrix was obtained.

In experiments in which the simulated overburdens exceeded $9 \mathrm{~cm}$, a static bubble formed on top of the inlet (Figure 8). The bubble did not change size (width or height) through time, at a given (constant) pressure. The presence of the static bubble also induced lateral compaction of the matrix, together with a moderate uplift resulting in two steeply dipping reverse shear bands on each side of the inlet (Figure 8, $\mathrm{t} 3$ and $\mathrm{t} 4$ ). The dip angle and diameter of the conical reverse shear bands are influenced by the filling height, with increasing values for additional material filling. When further increasing the pressure to values beyond the equilibrium threshold, the bubble rapidly moved toward the surface initiating the fluidization.

Fluidization is characterized by rapid upward transport of the grains together with the ascending bubble. This transport enables convective movement aligned with the inlet and at the center of the structure. This convective flow generated inward dipping beds at both sides of the fluidization zone. The concentration of fluidized deformation was centralized within the reverse shear bands. At the surface above the fluidization zone, crater deposits formed as grains were erupted (Figure 9).

We have compared the results from the Hele-Shaw cell with those from the seismic interpretation. Although HTVCs are symmetrical 3D structures and the sandbox experiment resulted in 2D-confined structures, the cor-
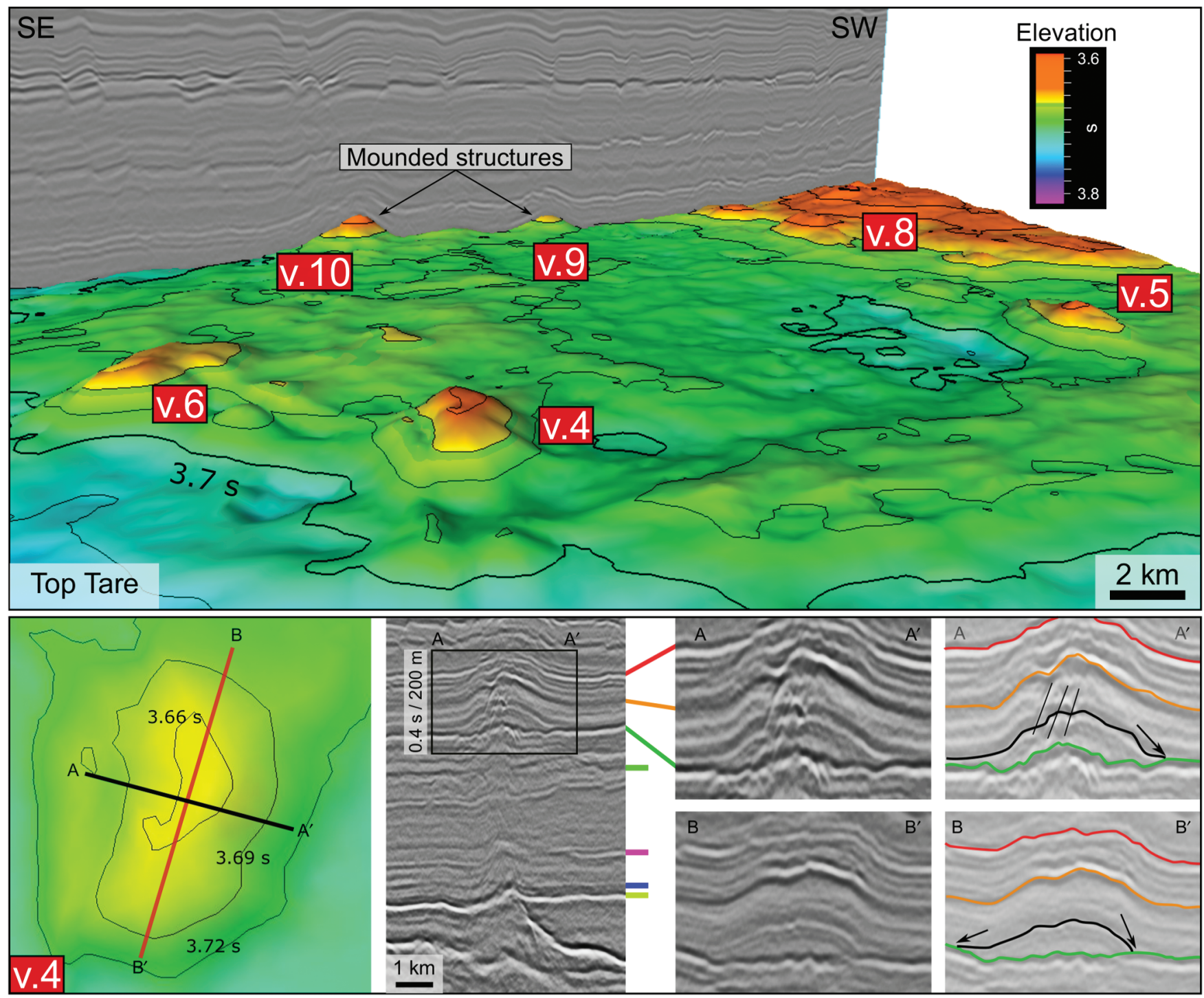

Figure 5. Perspective view of the intra-Eocene (lower) horizon Top Tare and a seismic crossline section of the representative mounded structures of the HTVCs. The seismic section below displays the HTVC v.4. Note that the structure is restricted between the intervals of the Paleocene-Eocene (between the sill tip at the Base Carbonate layer and the dome at Top Tare). 
a)

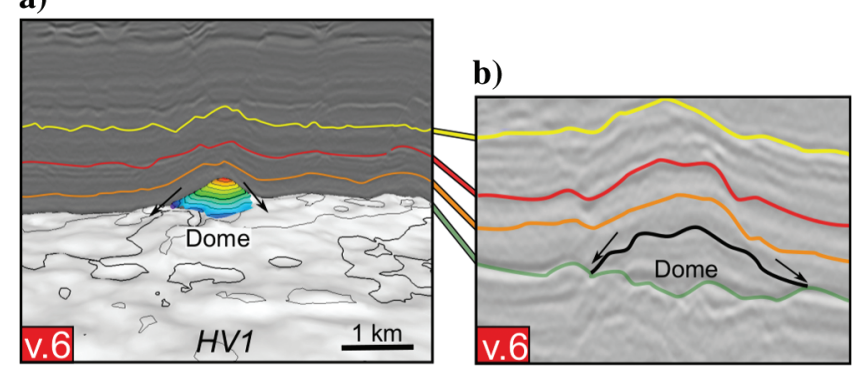

c)

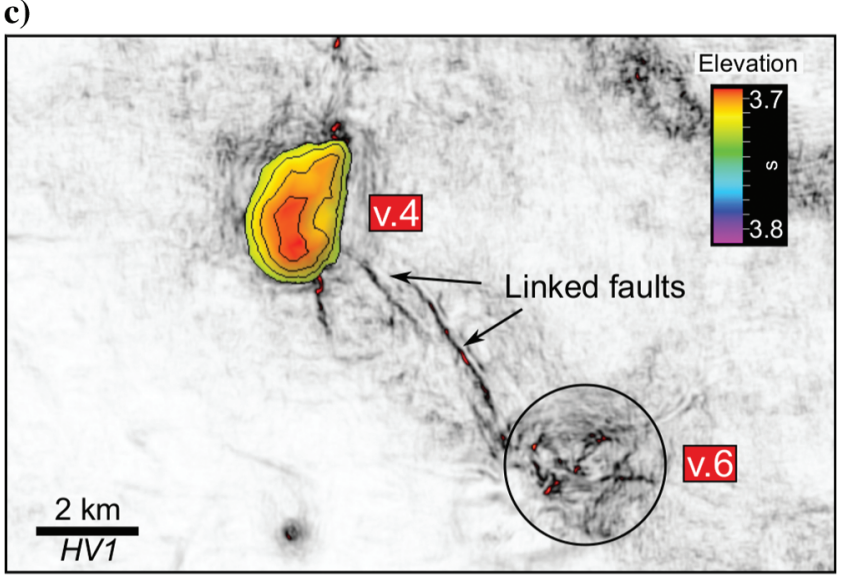

Figure 6. (a) 3D seismic interpretation of the v.6 dome structure, down-lapping onto the HV1 horizon. (b) Corresponding $2 \mathrm{D}$ projection of the v.6 dome structure. (c) "Variance cube" slice from the HV1 horizon seen from above. This figure illustrates the 3D mapped and time-slice variance representation of domes v.4 and v.6. The variance cube highlights lateral discontinuities such as faults. The fault pattern away from both vents suggests development simultaneous to the vents formation.

Table 1. List summarizing the measured parameters for the 13 HTVCs mapped in this study.

\begin{tabular}{lcccc}
\hline $\begin{array}{l}\text { HTVC } \\
\text { nr. }\end{array}$ & $\begin{array}{c}\text { Major } \\
\text { width (m) }\end{array}$ & $\begin{array}{c}\text { Minor } \\
\text { width (m) }\end{array}$ & $\begin{array}{c}\text { Dome } \\
\text { height (m) }\end{array}$ & $\begin{array}{c}\text { Conduit } \\
\text { height (m) }\end{array}$ \\
\hline 1 & $1400 \pm 100$ & $1200 \pm 100$ & $100 \pm 20$ & 400 \\
2 & $950 \pm 150$ & $600 \pm 100$ & 70 & 200 \\
3 & $1650 \pm 100$ & $1400 \pm 100$ & 90 & 320 \\
4 & $2100 \pm 50$ & $1800 \pm 100$ & 100 & 640 \\
5 & $2500 \pm 100$ & N/A & $120 \pm 50$ & 400 \\
6 & $1850 \pm 50$ & $1350 \pm 100$ & 80 & 630 \\
7 & $1600 \pm 100$ & N/A & $100 \pm 30$ & 630 \\
8 & 1200 & N/A & N/A & 530 \\
9 & $1200 \pm 20$ & $650 \pm 20$ & 85 & 500 \\
10 & 1570 & 1150 & 90 & 450 \\
11 & $300 \pm 50$ & N/A & 120 & 400 \\
12 & $1000 \pm 30$ & $600 \pm 30$ & 80 & 500 \\
13 & $1500 \pm 50$ & $1350 \pm 50$ & 85 & 650 \\
\hline
\end{tabular}

Note: See Figure 4 for the location of the individual complexes in which the specific part of the HTVCs could not be measured with confidence, and N/A (not available) is entered in the table. relation between basic parameters such as height, width, and length is still valid. Figure 10 shows similarities between the upper part of the HTVCs and the upper part of the sandbox structures. The plots indicate how crater/ dome structures scale approximately linearly with the
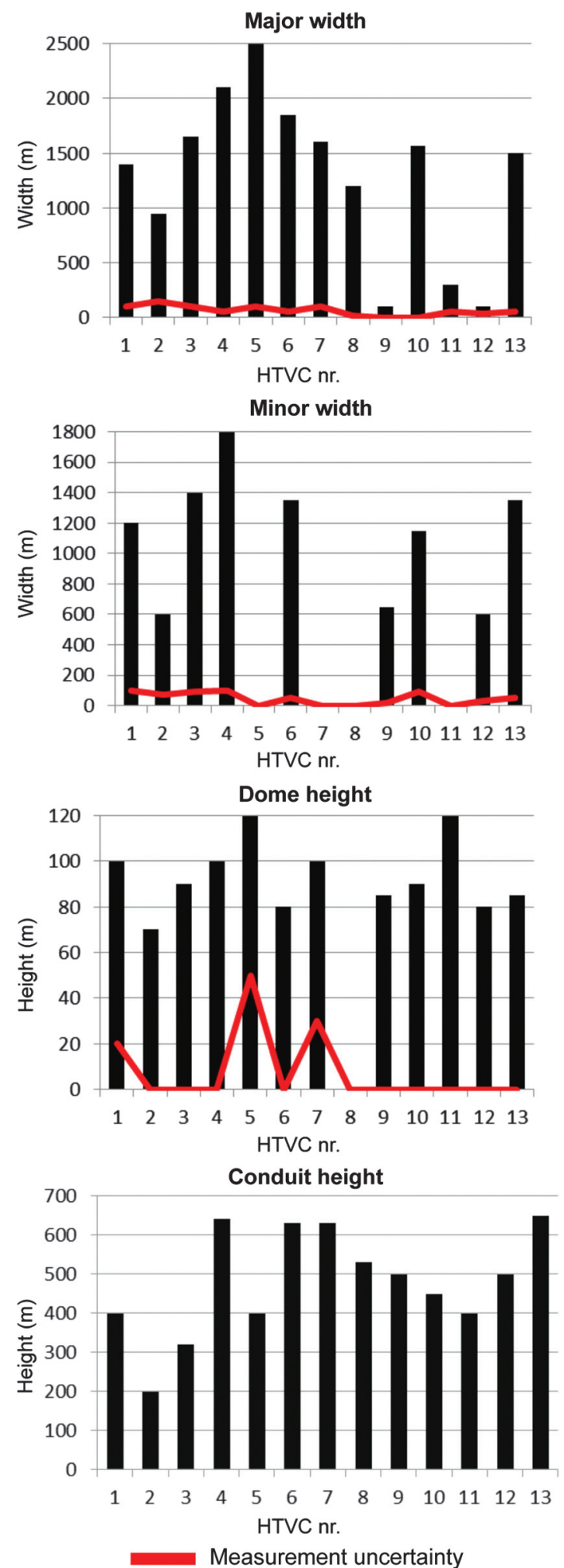

Figure 7. Bar diagram showing the dome sizes for the measured HTVCs in Table 1. 
conduit/filling height ratio. This is a trend that is also obtained from the seismic data, in which taller conduit zones are associated with larger surface (Table 1). Although a linear correlation may not represent the best fit in terms of the actual HTVCs, the height/width dependency is significant. Therefore, the sandbox models capture first-order features of the natural HTVC.

\section{Seismic modeling}

By estimating a simple overburden model and taking into account the combination of survey/migration aperture, we can retrieve and highlight the illuminated reflections at a given depth interval and reference point (Lecomte et al., 2015). In practice, the illumination of the target depends on the survey geometry and the wave propagation in the overburden, and it will also vary according to the location of the target (lateral and depth). Our seismic modeling allowed for direct control of what would be the maximum dip illuminated at the target, i.e., all reflection dips between the horizontal dip and the maximum dip imaged (Lecomte et al., 2016). Therefore, three maximum illuminated dips were tested during the seismic modeling procedure $\left(25^{\circ}, 45^{\circ}\right.$, and $\left.90^{\circ}\right)$, corresponding to limited, reasonable, and perfect (ideal) survey/migration apertures, respectively (Figure 11).

The synthetic model was able to capture complex features of the piercement structure and produce realistic geometries and deformation fields. Although the differences between $25^{\circ}$ and perfect $\left(90^{\circ}\right.$ max dip) illumination may be subtle, there are differences due to resolution and geometric effects. From the $25^{\circ}$ max dip, features exceeding the $25^{\circ}$ incline angle will disappear in the seismogram (black arrows in Figure 11). In addition, the disrupted conduit zone appears as blurry and transparent in the seismogram compared with the $45^{\circ}$ and perfect illumination. This observation supports that a narrow survey aperture prohibits steeper reflections to be illuminated compared with a wide aperture. The $45^{\circ}$ corresponds to symmetrical illumination of the modeling. Angles exceeding $45^{\circ}$ max dip are not illuminated in the seismogram. Note that the steeper dipping reflections in the conduit zone seem to have a more lateral and continuous extension. When comparing the conduit interior between the $45^{\circ}$ and the perfect illumination, the latter is slightly improved with respect to reflection strength.

\section{Discussion}

The hydrothermal vent complexes provide evidence for focused fluid and gas migration in the Møre Basin close to the Paleocene-Eocene transition. A few questions arise from our mapping, including aspects of the detailed interpretation of the seismic data and the age of the HTVCs. The key to these questions can be constrained by examination of the seismic and stratigraphic data, and the experimental and synthetic modeling. The discussion below focuses on the HTVCs as one complete system, including morphology, formation mechanisms, and age correlations.

\section{Dome shape and differential compaction model}

A characteristic feature associated with the explosive volcanism of hydrothermal venting is the formation of craters (Nermoen et al., 2010; Haug et al., 2013; Galland et al., 2014). The opposite is found regarding the HTVCs interpreted in the 3D cube, i.e., domes and not craters. The formation of HTVCs at the HV1 horizon shows a characteristic down-lapping dome structure on the paleosurface defining the upper part (Figure 6).
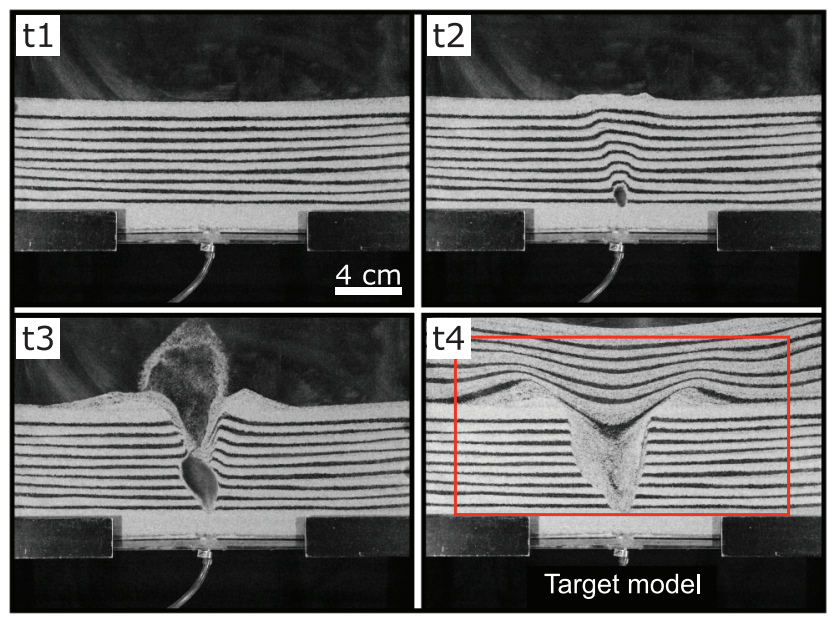

Figure 8. Time-lapse sequence of sandbox experiment. (t1): Initial configuration of the static bedding. (t2): Static bubble forming at the centered inlet, fluid-induced deformation of the matrix. (t3): The gas bubble grows to the surface, triggering the onset of fluidization and eruption of material at the structure rim and crater. (t4): Resedimentation of piercement structure, material funnel fed after experiment.

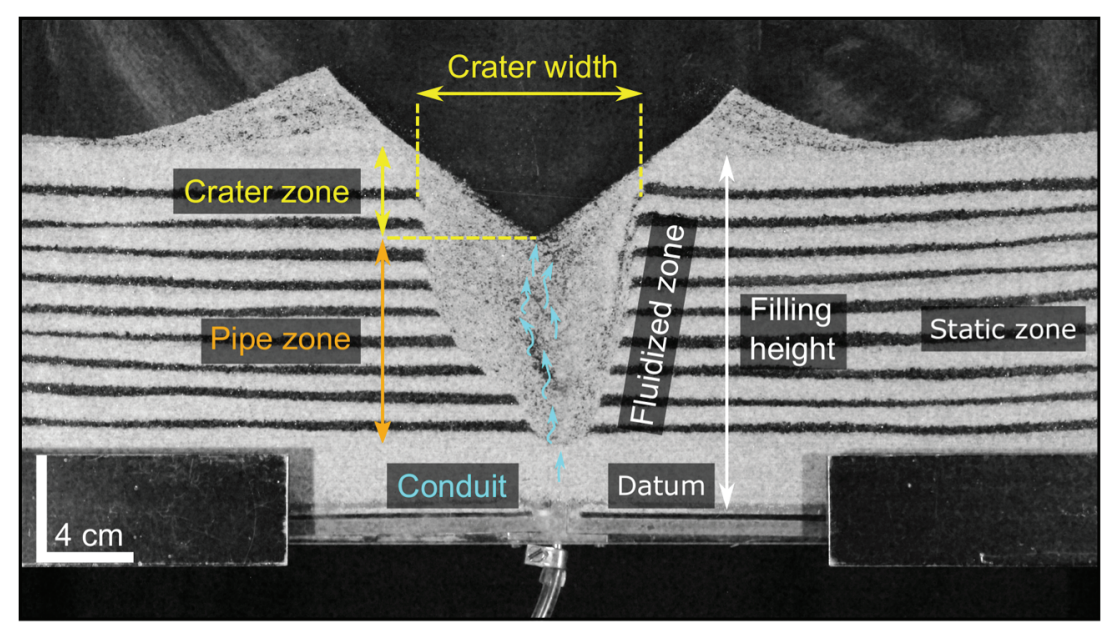

Figure 9. Morphological zones defined in the experiment, which enable a correlation to the natural occurring HTVCs. 
Differential compaction is a mechanism that may explain the doming above the HTVCs.

All materials will compact due to gravitational stresses when loaded. Differential compaction develops, for instance, in inhomogeneous sedimentary deposits, in which the material properties vary (Miles and Cartwright, 2010; Jackson, 2012; Zhao et al., 2014). Variation in how the different materials behave during this process is dependent on their composition and porosity. The result can be seen as local areas compact-
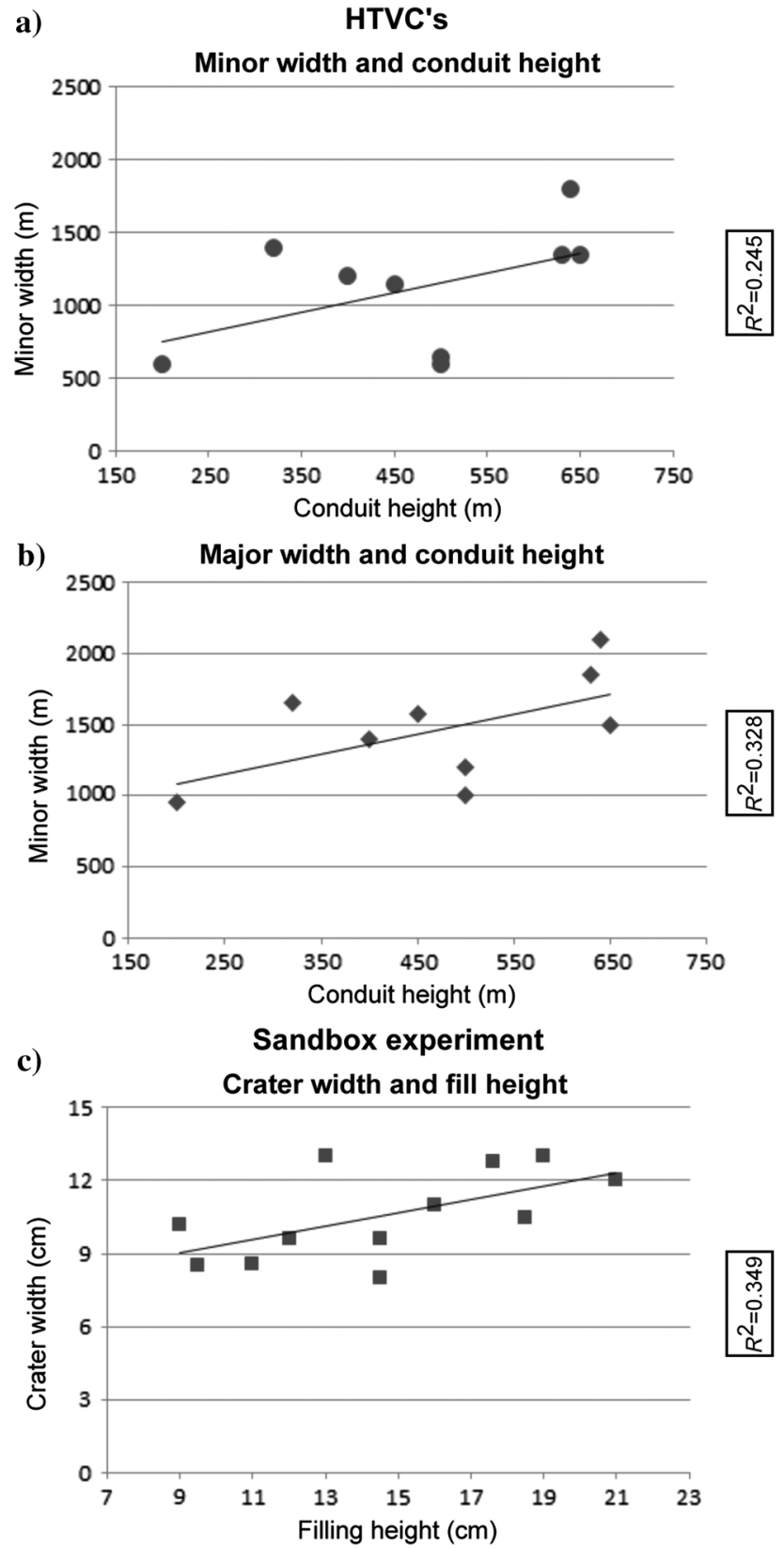

Figure 10. Comparison plot between HTVCs and piercement structures in the sandbox experiment: (a) Minor width plotted against the conduit height. (b) Major width plotted against the conduit height. (c) Crater width plotted against filling height (in a sandbox experiment). ing more than others, and that geologic structures may be affected geometrically during compaction stresses (Figure 12). This process has previously been described in terms of the upper vent geometry by Skogseid et al. (1992) and Planke et al. (2005), in which it was considered as a possibility for the vent-fill to compact less than the surrounding strata, thus, causing the characteristic dome morphology.

The presence of long-lived seepage through vents from underlying strata (Svensen et al., 2003; Iyer et al., 2013) could also have contributed to the reduced compaction of the vent structure. If these fluids migrated and were trapped in the upper vent structure by the deposition of overlying sealing sediments, overpressure could have developed, which in turn may have inhibited further compaction.
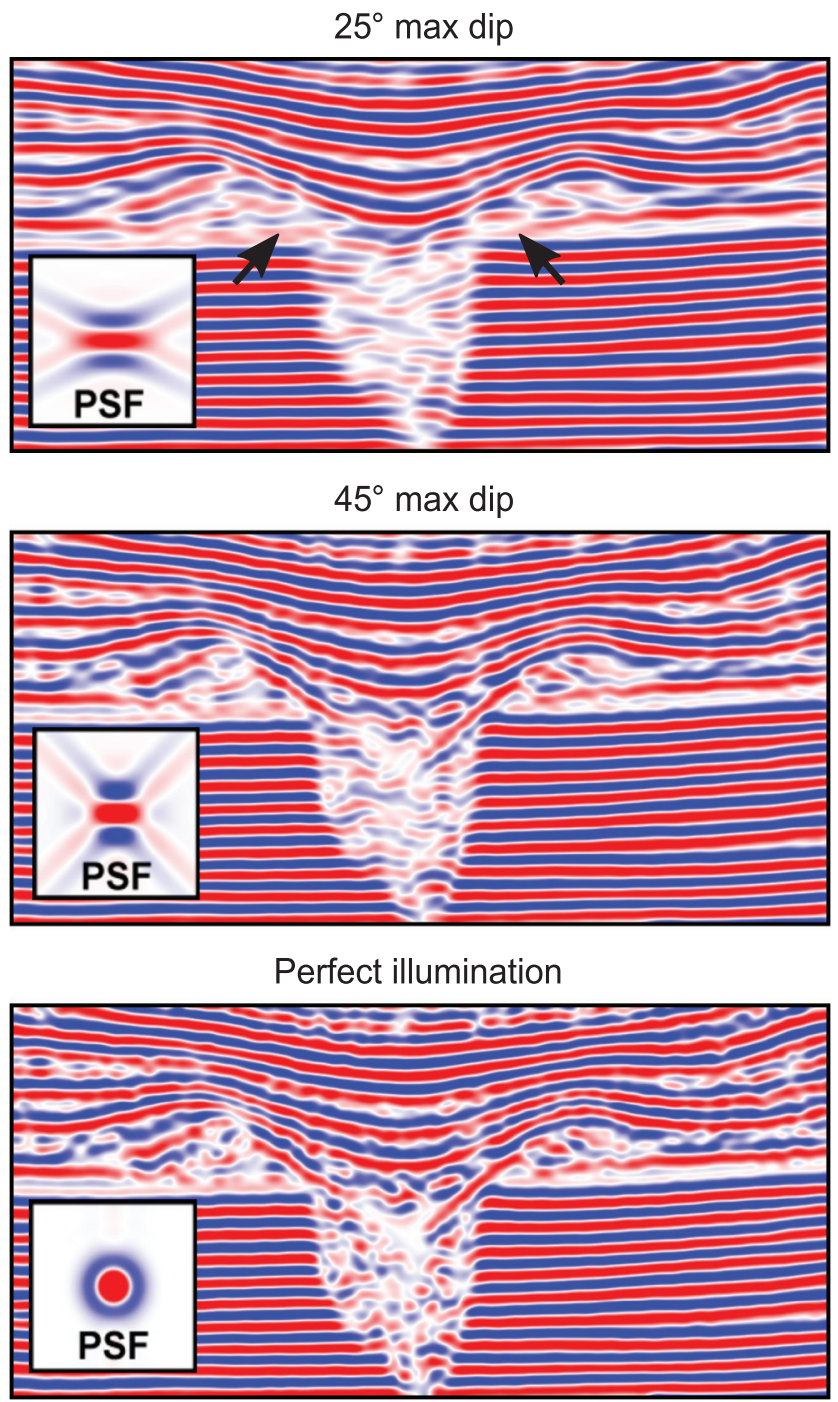

Figure 11. Synthetic seismic modeling of a model derived from the sandbox experiment. Elastic properties based on well 6302/6-1 at the HTVC interval. Arrows in the uppermost figure highlight how different reflection dips are affected by seismic imaging. 


\section{HTVC formation and the sandbox experiment}

It is clear that the HTVCs result from focused fluid flow to generate the structural features seen in the seismic data. We have identified similarities when comparing seismic cross sections of HTVCs with the sandbox experiments (Figures 3 and 9). When fluid pressure was increased beyond the equilibrium threshold, fracturing and brecciating developed above the source. The fluidized zone in the sandbox experiment acted as the conduit zone in the natural setting, a pathway for fluids to reach the surface. The fluidization in the sandbox experiment developed two regions where the first consisted of a narrow conduit zone and the second an upper crater zone (Figure 9). These two morphological features can be correlated to the upper and lower parts of the HTVCs (see Jamtveit et al., 2004; Planke et al., 2005).

Field data show that the HTVCs contain brecciated sedimentary rocks with lithologic differences compared with the surrounding strata (Jamtveit et al., 2004; Svensen et al., 2006). Similar findings are evident from the conduit zone in the sandbox experiment. Moreover, the field observations, and seismic and experimental data show well-developed inward dipping strata toward the conduit zone (Planke et al., 2003; Svensen et al., 2006). The experiment time-lapse photographs of Figure 8 show convective flow during material transport, resulting in volume reduction followed by collapse and the generation of inward dipping beds.

The main difference between the sandbox models and the seismic data are the shallow structures: The sandbox exhibits well-developed crater morphology above the in-filled fluidized conduit zone, whereas HTVCs interpreted in the 3D cube exhibit domes. As mentioned earlier, we interpret these domes as a result of differential compaction, a process that cannot be modeled in the sandbox.

\section{Synthetic seismic}

Synthetic modeling emphasizes the importance of internal structures in generating seismic amplitude anomalies. Figure 11 shows a comparison between the different modeling runs. Even though the resulting seismic images a)

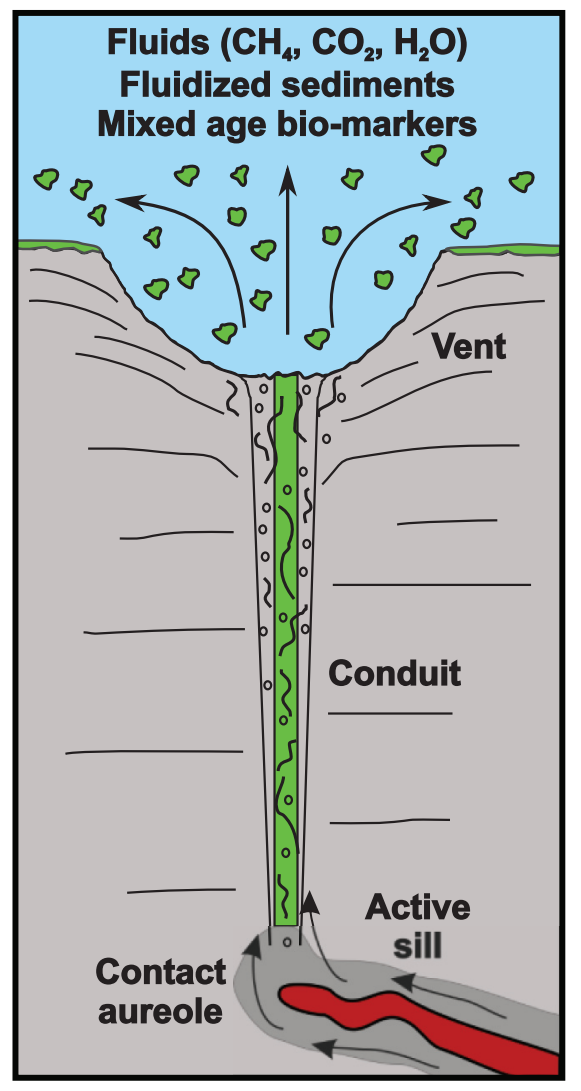

b)

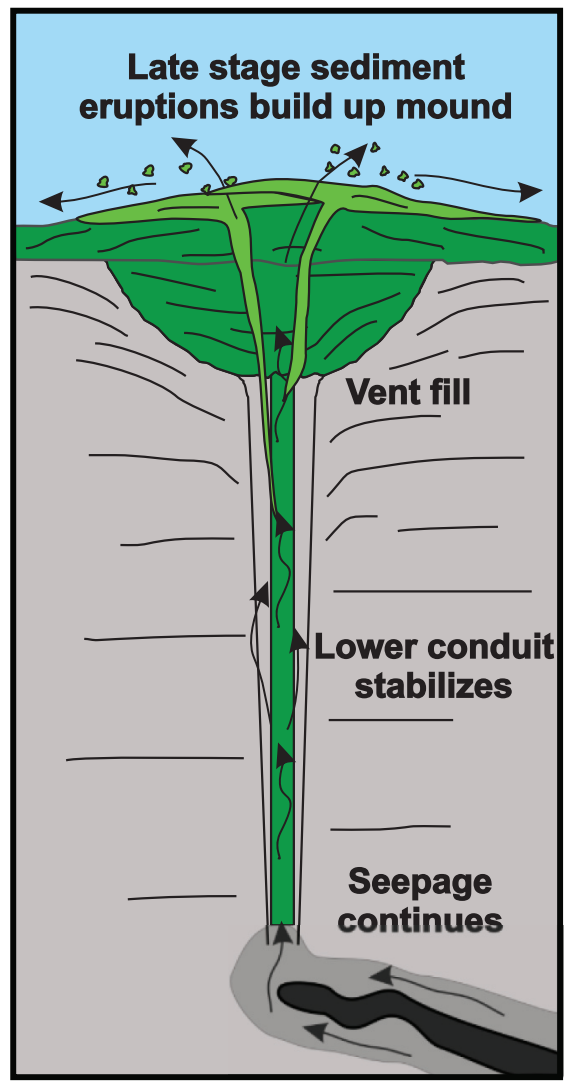

c)

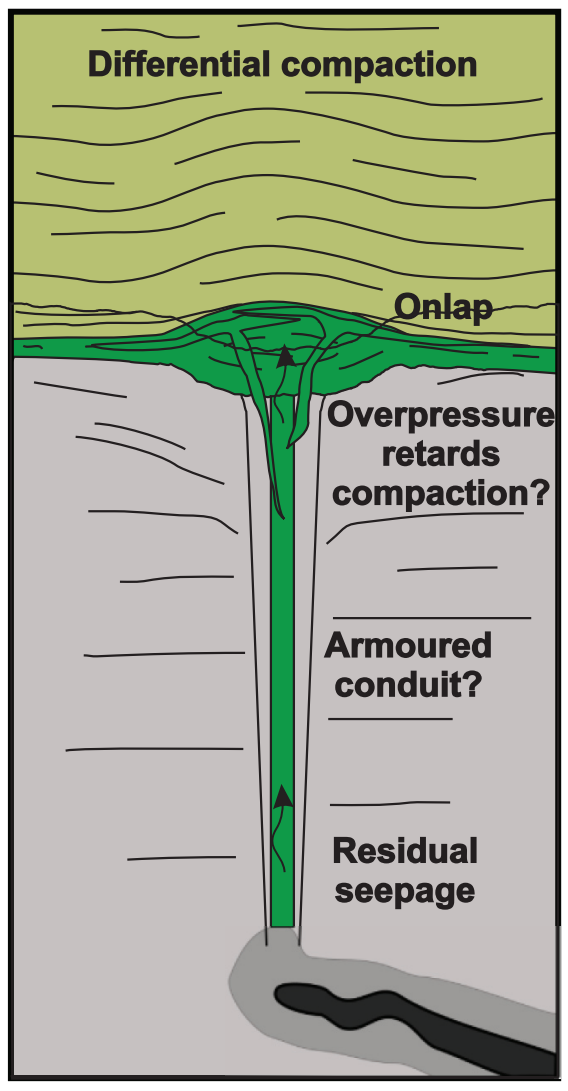

Figure 12. Schematic model displaying key development stages during vent formation. (a) Emplacement of intrusion promotes fluid generation and overpressure causing overburden failure and explosive hydrothermal venting, which blankets the surrounding area with vent material and older sediments. Large volumes of carbon out gassed into the water column and atmosphere. (b) After the initial high-energy venting, activity gradually wanes with long-lived gas seepage occurring over many thousands of years and periodically promoting small-scale sediment eruptions, which fill the crater and build up a shallow angle dome. (c) Post venting sedimentation blankets the dome and builds up a potentially sealing cover over thousands to millions of years. Compaction of surrounding strata may exceed that of the hardened or potentially over-pressured vent material resulting in differential compaction and the accentuation of the dome feature. 
produced are generically similar, there are clear structural differences. One of the most prominent characteristics when comparing the $25^{\circ}-45^{\circ}$ max dip is how the reflections in the images are displayed (Figure 13). By widening the survey distance and migration aperture in the model, steeper reflection dips at a given reference point are obtained. Perfect illumination has the widest survey/migration aperture, and $25^{\circ}$ is the narrowest. Comparing the seismic and the synthetic section, the near-horizontal reflections are displayed properly, but this is not the case for the dipping reflections. The combination of the survey aperture and layer dip makes for two different structural interpretations of the seismograms. When comparing these results to the actual seismic section of the HTVCs, we find that the dipping reflections in the conduit zone rarely exceed c. $45^{\circ}-50^{\circ}$. From the seismic modeling, we found out that $45^{\circ} \max$ illumination dip was reasonable for the considered overburden model and a standard migration aperture value. This may imply that the processed data are unable to properly visualize reflections above this angle. A reasonable maximum illuminated dip is taken to be approxi- mately $45^{\circ}$, and it seems to fit between our modeling estimation and what is observed on the actual images.

A direct implication of this is that strongly dipping structural features within the HTVCs can be overlooked or misinterpreted (Figure 13). The synthetic modeling thereby provides a method for more confident interpretations of geologic features, plus the ability to validate seismic attributes and artifacts to avoid pitfalls and misinterpretations.

\section{Age and evolution of the More Basin vent complexes}

Age determination of the HTVCs in this study is based on the seismic interpretation, well-tie correlations and published palynological data focusing on the sediments at the upper HTVC interval. The interval between the HV1 and HV3 horizons represents the development and emplacement of the HTVCs. These observations include the intrusive nature of the conduit zone below this transition zone, down-lapping domes, radial faults and tuffaceous claystone at the paleosurface of HV1. From the well data and check shots, the measured depth of this a)

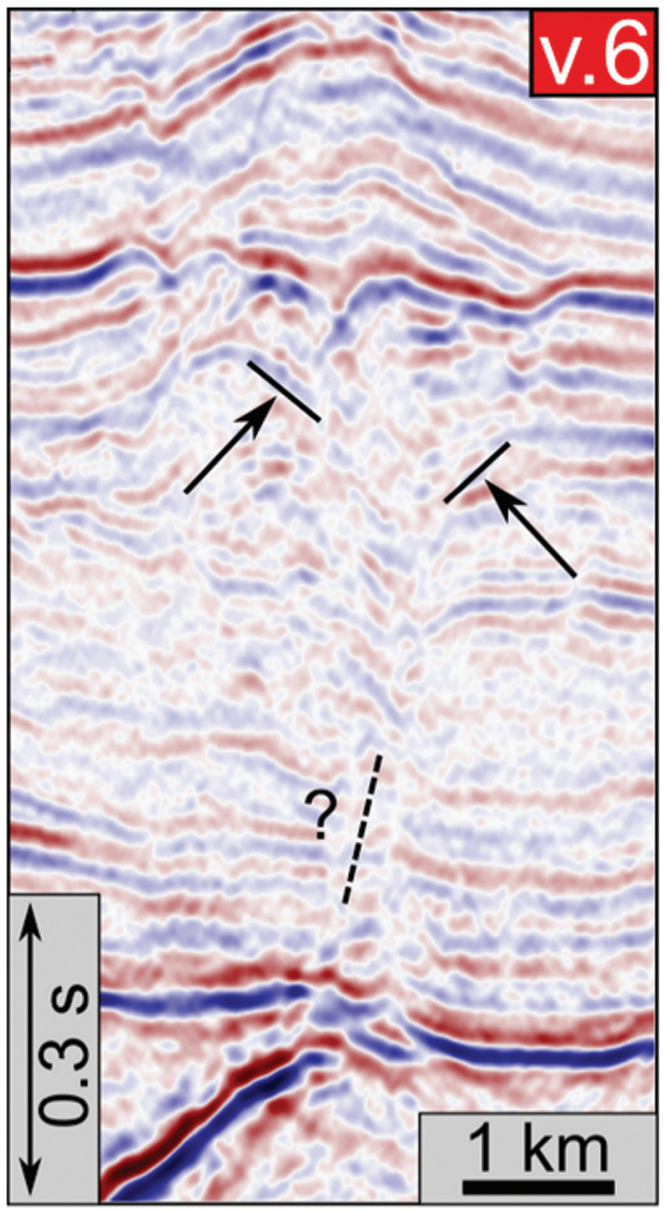

b)

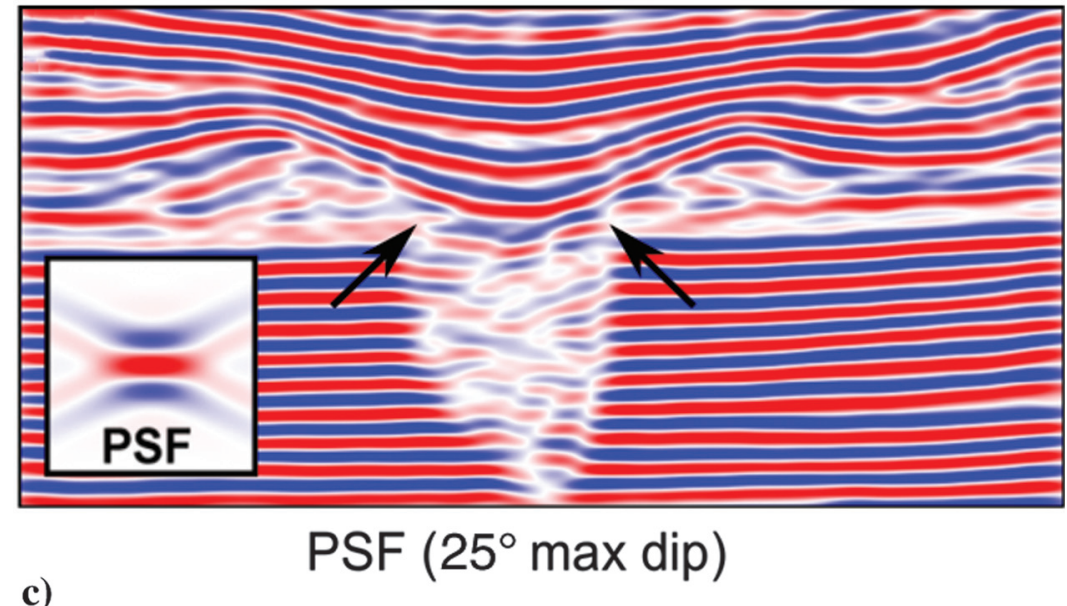

c)

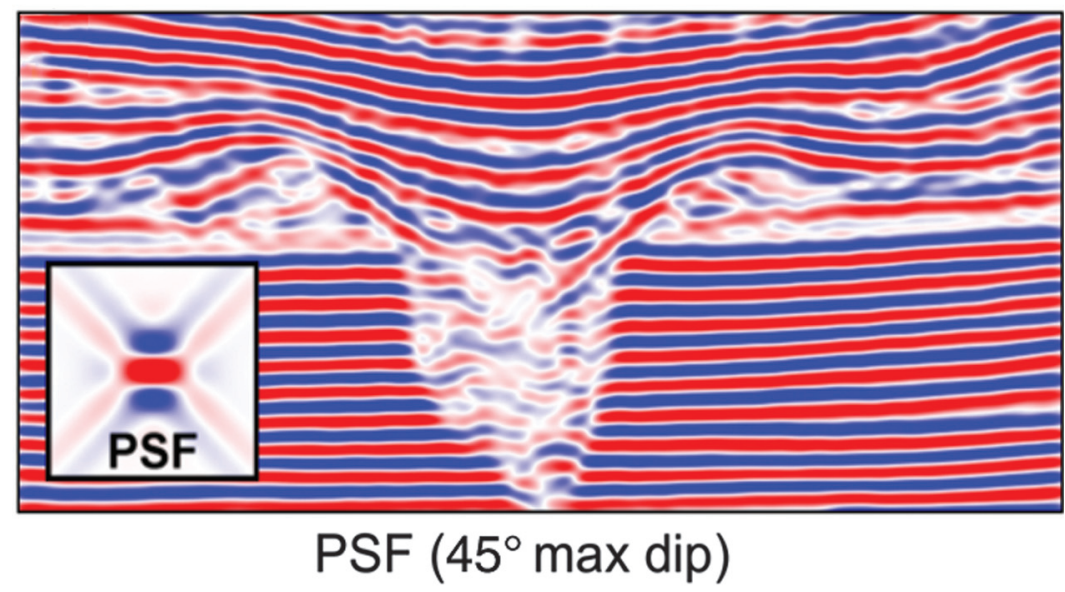

Figure 13. (a) HTVC (v.6) seismic section, illustrating how the dipping reflections are displayed in the image, and the uncertainty that follows with steeper dipping reflections. (b) $25^{\circ}$ max dip illumination in the seismogram. Restricted illuminated reflections greater than $25^{\circ}$. The black arrows indicate structural differences between the two angel-dependent models. (c) $45^{\circ}$ max dip illumination in the seismogram. The dominant frequency of the seismic is $20 \mathrm{~Hz}$. 
interval is correlated to be between 3350 and $3450 \mathrm{~m}$ (Figures 14 and 15).

The biostratigraphic evidence from this transition zone comprises a somewhat enigmatic assemblage with mixed-age biostratigraphic indicators between the clear signatures from the underlying Tang and overlying Tare Formations. Clear and clean occurrences of the dinocyst Apectodinium augustum are identified at 3350

a)

\begin{tabular}{|c|c|c|c|c|c|c|}
\hline $\begin{array}{c}\text { Sample } \\
\text { depth }(m)\end{array}$ & TWT (s) & Key taxa & $\begin{array}{l}\text { Palyno } \\
\text { zones }\end{array}$ & $\begin{array}{l}\text { Time } \\
\text { scale }\end{array}$ & $\underline{E}$ & Age $\mathrm{Ma}$ \\
\hline $3090-3120$ & $3.574-3.607$ & Diphyes colligerum (LO) & TP8A & & & $41.30-$ ca. 42.80 \\
\hline 3180 & 3.671 & $\begin{array}{l}\text { Eatonicysta ursulae \& } \\
\text { Azolla spp. }\end{array}$ & TP6D2 & & 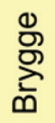 & $50.02-$ ca. 50.10 \\
\hline $3200-3220$ & $3.688-3.704$ & Dracodinium politum (LO) & TP6B & (1) & & $50.29-$ ca. 50.50 \\
\hline $3240-3250$ & $3.725-3.733$ & $\begin{array}{l}\text { Deflandrea } \\
\text { oebisfeldensis (LO) }\end{array}$ & TP5B4 & نํำ & & $51.50-53.61$ \\
\hline $3270-3330$ & $3.750-3.800$ & Cerodinium wardenense & TP5B2 & & & $54.60-54.70$ \\
\hline $3350-3400$ & $3.820-3.862$ & Apectodinium augustum & $\overline{\text { TP5A }}$ & & TZ & $54.90-55.80$ \\
\hline $3450-3570$ & $3.902-4.003$ & Glaphyrocysta 'oligacantha' & TP3B3 & Paleocene & ర్ & $57.40-57.90$ \\
\hline
\end{tabular}

b)

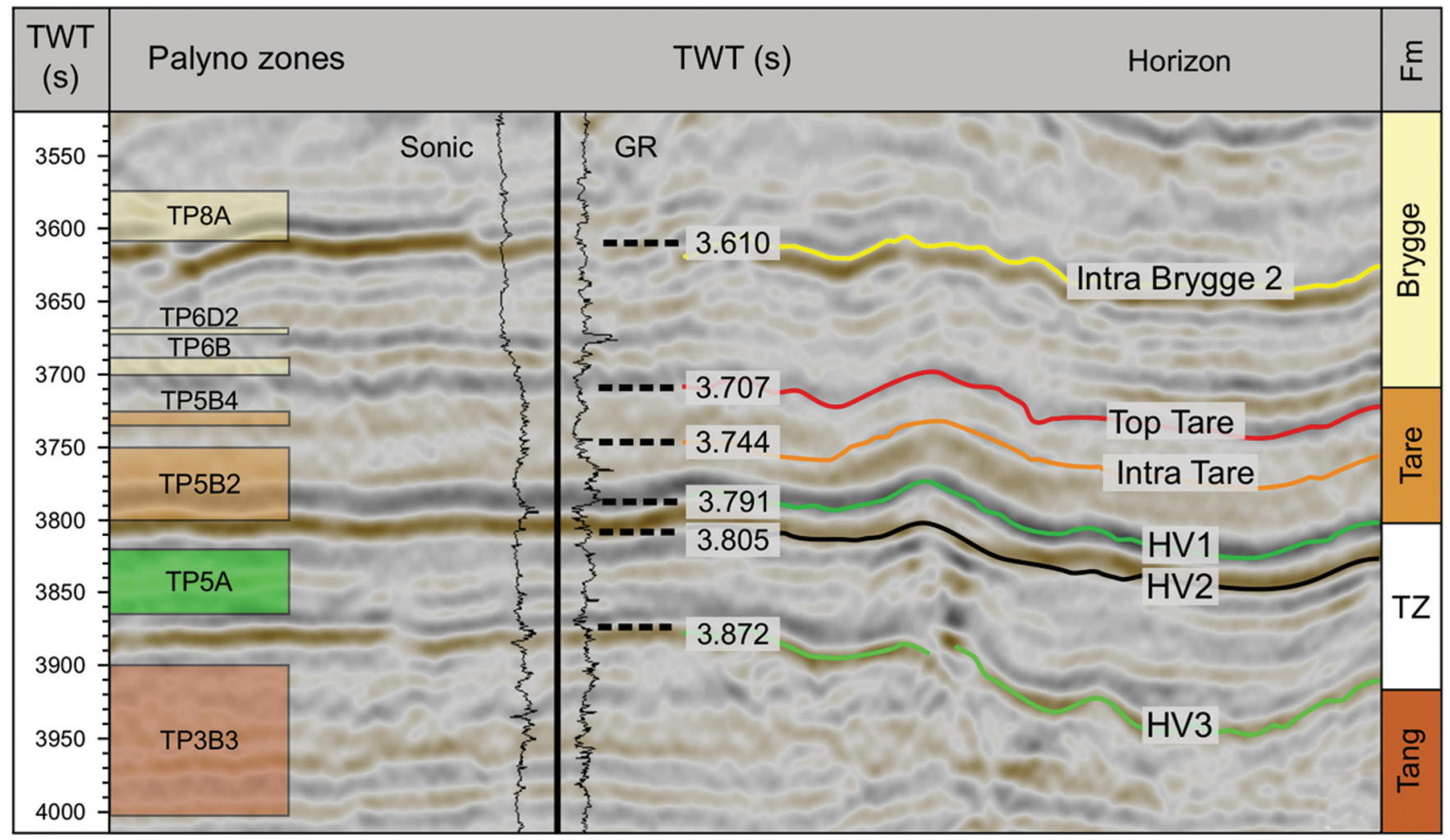

Figure 14. Summary of biostratigraphic age constraints of the venting interval. (a) Table showing the key taxa distributions correlated with relative age and horizons interpreted at the HTVC interval. Palynozones correspond to taxa distribution at given time stages. (b) Seismic section and taxa resolution of the HTVC interval. Depth of the seismic horizons calibrated with check-shot data from well 6302/6-1. 
and $3390 \mathrm{~m}$ (last natural occurrence, LO in the well) which suggests that the interval most likely comprises the TP5A zone of the Earliest Eocene (Figure 14). This species is widely used as a marker species for the Paleocene-Eocene transition (Ali and Jolley, 1996; Schmitz et al., 2004; Sluijs et al., 2006; Passey and Jolley, 2009). Classification of the interval is complicated by the occurrence of older Paleocene palynomorphs (e.g., Tang markers such as Alisocysta margarita, Palaeoperidinium pyrophorum, Areoligera gippingensis, Spiniferites "membranispina"; note that these did not occur in the expected order) along with the frequent occurrence of Cretaceous fossils like Sidridinium borealis, "ancient" bisaccates, and Upper Triassic Ricciisporites tuberculatus. The interval may therefore represent the upper parts of the Tang Formation with abundant caving from zone TP5A, or alternatively in situ TP5A with reworking from Tang and older formations. The mixed nature of the assemblage supports significant reworking within the interval, and therefore the clear occurrences of $A$. augustum are used to support an Earliest Eocene (54.9-55.8 Ma) age for the transition zone and therefore the HTVC development within the Møre Basin study area (Figure 14).

A wide range in thermal maturity of the retrieved fossils is documented from the transition zone suggesting a source near the sill. For instance, some of the Cretaceous and older reworked fossils are almost black in 3410-3440 m. Tuffaceous material was also identified within the interval. Along with the high temperature signatures, older sediments and volcanic detritus indicate that local and basin-wide eruptions, causing plumes of mixed age sedimentary rocks along with their biomarkers (Schofield et al., 2015), could have contributed to the mixed assemblages of the transition zone at this time.

\section{Paleocene-Eocene thermal maximum}

The HTVC formation coincides with one of the most extreme transient shifts in climate during the Cenozoic. The PETM occurred at approximately $56 \mathrm{Ma}$ and lasted between 100 and 200 kyr (Norris and Röhl, 1999; Westerhold et al., 2009). This event is associated with a significant temperature rise of the oceans and the atmosphere, together with changes in ocean chemistry and extinction of benthic foraminiferal species traceable in the biostratigraphical record (Kennett and Stott, 1991; Röhl et al., 2000; Röhl et al., 2007).

The PETM is coeval with the initial opening of the northeast Atlantic Ocean (Storey et al., 2007), which has been linked to magma emplaced in the Møre Basin (Svensen et al., 2004; Frieling et al., 2016). Although no direct evidence for contact aureoles have been identified during the seismic interpretation, contact metamorphism around sills is well understood and led to the generation of $\mathrm{CH}_{4}, \mathrm{CO}_{2}$, and $\mathrm{H}_{2} \mathrm{O}$ from heating of organic-bearing sedimentary rocks (Aarnes et al., 2015). Vent complex statistics from the Møre and Vøring Basins by Planke et al. (2005) indicate that potentially thousands of individual HTVCs formed within the PETM and may have acted as one of the main sources for carbon (Svensen et al., 2004). Sedimentary basins influenced by large igneous provinces may thus represent settings characterized by rapid release of carbon-bearing gas.

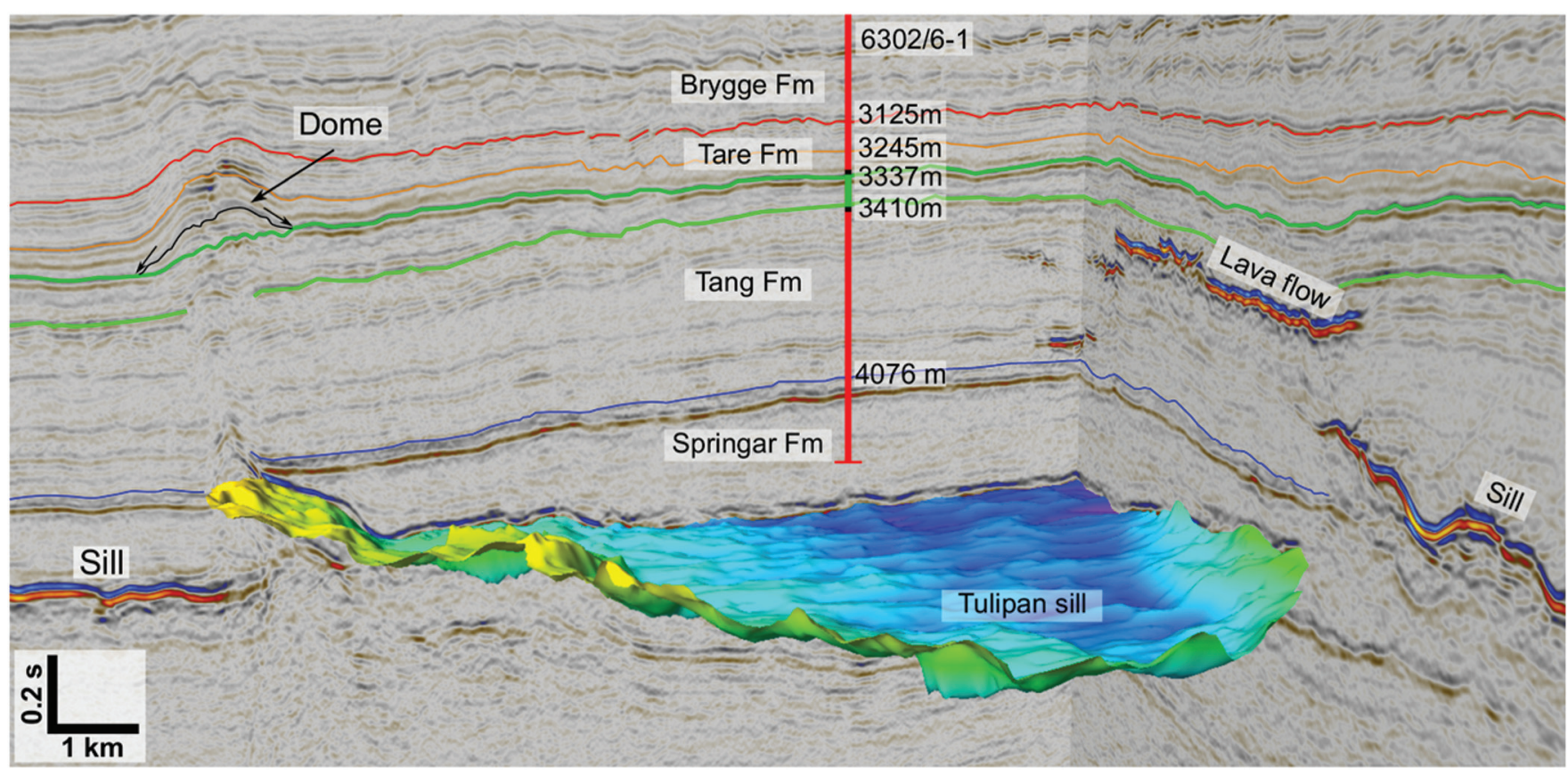

Figure 15. Figure summarizing different data implemented to resolve the key questions regarding the HTVCs in the Møre Basin. The investigation focus on (1) the vent complex geometries, (2) the induced surface deformation patterns, (3) the intrusions (heat source) relation, as well as (4) the emplacement depth and age of the hydrothermal vent complexes. 


\section{Conclusions}

Seismic mapping in the Møre Basin offshore mid-Norway has documented an extensive hydrothermal vent complex of Paleocene-Eocene age. Thirteen individual vent complexes have been mapped within the $310 \mathrm{~km}^{2}$ large study area. All the observed venting structures are located above sill intrusions and are therefore assumed to have developed as a direct consequence of sill emplacement and contact metamorphism. The complex architecture of the HTVCs may be explained by mobilization of sedimentary rocks from above the sills, caused by local fluid overpressure and fluid migration. The HTVCs were formed primarily during explosive eruption of gases, liquids, and sedimentary rocks, resulting in depressions and craters at the seafloor. The upper parts of the HTVCs are dominated by domes and mounded features measuring up to $2.5 \mathrm{~km}$ in diameter and $120 \mathrm{~m}$ in height. The upper parts of the vent complexes terminate consistently at the Paleocene-Eocene transition above the Tang Formation. This study has used state-of-theart methods to produce unique 3D images of seismic reflection data together with simulated modeling to map out the HTVCs within the Møre Basin. The methods used demonstrate how the final analyses can provide new images of sediment deformation and fluid/gas migration patterns using 3D seismic and modeling procedures. Combining these makes it possible to recognize geometries with considerable confidence, along with mapping important relationships between fluid-flow pathways and structural behavior with high precision.

By implementing well-tie correlations and biostratigraphical analysis, the ages of these structures are within the 54.9-55.8 Ma range. This period is characterized by intrusive events during the initial volcanism phase at the mid-Norwegian margin, corresponding to the northeast Atlantic breakup. The hydrothermal vent complexes were likely active for a substantial time period in the earliest Eocene. The vent formation likely corresponds to a c. $100 \mathrm{~m}$ thick Tang/Tare transition zone with A. augustum and reworked Cretaceous and older fossils displaying high maturities possibly caused by contact metamorphism. The timing of the HTVCs coincides with one of the most extreme climatic shifts in the Cenozoic, the PETM, and our data and conclusions stress the link between the generation and release of carbon gases from the Møre Basin and the global environmental change.

\section{Acknowledgments}

We thank Statoil for providing us with the PL251 (Tulipan) geophysical and geologic reports for well 6302/61 . We thank NORSAR for the free academic use of the SeisRox software during the modeling procedures and to Schlumberger for the free academic use of Petrel 2015. Spectral decomposition was carried out using FFA Geoteric software at the University of Aberdeen. FFA are thanked for donation of the software license to the University of Aberdeen. The authors further acknowledge the support from the Research Council of Norway through its Center of Excellence funding scheme, project 223272 (CEED), and from the MIMES project (grant no. 244155). We also gratefully acknowledge the support by the Faculty of Mathematics and Natural Sciences of the University of Oslo to TS. Clayton Grove and Craig Magee are thanked for their many insightful comments and suggestions that helped improve the paper substantially.

\section{REFERENCES}

Aarnes, I., S. Planke, M. Trulsvik, and H. Svensen, 2015, Contact metamorphism and thermogenic gas generation in the Vøring and Møre basins, offshore Norway, during the Paleocene-Eocene thermal maximum: Journal of the Geological Society, 172, 588-598, doi: 10 .1144/jgs2014-098.

Aarnes, I., H. Svensen, J. A. Connolly, and Y. Y. Podladchikov, 2010, How contact metamorphism can trigger global climate changes: Modeling gas generation around igneous sills in sedimentary basins: Geochimica et Cosmochimica Acta, 74, 7179-7195, doi: 10.1016/j.gca.2010.09.011.

Ali, J. R., and D. W. Jolley, 1996, Chronostratigraphic framework for the Thanetian and lower Ypresian deposits of southern England: Geological Society, London, Special Publications 101, 129-144.

Bell, B., and H. Butcher, 2002, On the emplacement of sill complexes: Evidence from the Faroe-Shetland Basin: Geological Society, London, Special Publications 197, 307-329.

Berndt, C., C. Hensen, C. Mortera-Gutierrez, S. Sarkar, S. Geilert, M. Schmidt, V. Liebetrau, R. Kipfer,, F. Scholz, M. Doll, S. Muff, J. Karstens, S. Planke, S. Petersen, C. Böttner, W.-C. Chi, M. Moser, R. Behrendt, A. Fiskal, M. A. Lever, C.-C. Su, L. Deng, M. S. Brennwald, and D. Lizarralde, 2016, Rifting under steam-How rift magmatism triggers methane venting from sedimentary basins, Geology, 44, 767, doi: 10.1130/G38049.1.

Brekke, H., 2000, The tectonic evolution of the Norwegian Sea continental margin, with emphasis on the Vøring and Møre basins: Special Publication-Geological Society of London, 167, 327-378.

Dalland, A., D. Worsley, and K. Ofstad, 1988, A Lithostratigraphic scheme for the Mesozoic and Cenozoic and succession offshore Mid-and Northern Norway: Oljedirektoratet.

Deagan, C., and B. Scull, 1977, A proposed standard lithostratigraphic nomenclature for the Central and Northern Sea: Annual Report: Institute of Geological Sciences, Report no. 77/25: Bulletin NPD, no. 1.

Doré, A. G., E. R. Lundin, L. N. Jensen, Ø. Birkeland, P. E. Eliassen, and C. Fichler, 1999, Principal tectonic events in the evolution of the northwest European Atlantic margin: Geological Society of London, Geological society, London, petroleum geology conference series 5, 41-61.

Faleide, J. I., F. Tsikalas, A. jBreivik, R. Mjelde, O. Ritzmann, O. Engen, J. Wilson, and O. Eldholm, 2008, Structure and evolution of the continental margin off Norway and the Barents Sea: Episodes, 31, 82-91. 
Frieling, J., H. H. Svensen, S. Planke, M. J. Cramwinckel, H. Selnes, and A. Sluijs, 2015, Thermogenic methane release as a cause for the long duration of the PETM, 2015 AGU Fall Meeting, Agu.

Frieling, J., H. H. Svensen, S. Planke, M. J. Cramwinckel, H. Selnes, and A. Sluijs, 2016, Thermogenic methane release as a cause for the long duration of the PETM: Proceedings of the National Academy of Sciences 12059-12064, doi: 10.1073/pnas.1603348113.

Galland, O., G. R. Gisler, and Ø. T. Haug, 2014, Morphology and dynamics of explosive vents through cohesive rock formations: Journal of Geophysical Research, 119, 4708-4728, doi: 10.1002/2014JB011050.

Gernigon, L., J. C. Ringenbach, S. Planke, B. Le Gall, and H. Jonquet-Kolstø, 2003, Extension, crustal structure and magmatism at the outer Vøring Basin, Norwegian margin: Journal of the Geological Society, 160, 197-208, doi: 10.1144/0016-764902-055.

Gibb, F., and R. Kanaris-Sotiriou, 1988, The geochemistry and origin of the Faeroe-Shetland sill complex: Geological Society, London, Special Publications 39, 241-252.

Grapes, R., 2010, Pyrometamorphism: Springer Science \& Business Media.

Grove, C., 2013, Submarine hydrothermal vent complexes in the Paleocene of the Faroe-Shetland Basin: Insights from three-dimensional seismic and petrographical data: Geology, 41, 71-74, doi: 10.1130/g33559.1.

Hansen, J., J. Cartwright, M. Huuse, and O. R. Clausen, 2005, 3D seismic expression of fluid migration and mud remobilization on the Gjallar Ridge, offshore midNorway: Basin Research, 17, 123-139, doi: 10.1111/j 1365-2117.2005.00257.x.

Haug, Ø. T., O. Galland, and G. R. Gisler, 2013, Experimental modelling of fragmentation applied to volcanic explosions: Earth and Planetary Science Letters, 384, 188-197, doi: 10.1016/j.epsl.2013.10.004.

Heggland, R., 1998, Gas seepage as an indicator of deeper prospective reservoirs: A study based on exploration 3D seismic data: Marine and Petroleum Geology, 15, 1-9, doi: 10.1016/S0264-8172(97)00060-3.

Hjelstuen, B. O., O. Eldholm, and J. Skogseid, 1997, Vøring Plateau diapir fields and their structural and depositional settings: Marine Geology, 144, 33-57, doi: 10.1016/ S0025-3227(97)00085-6.

Iyer, K., L. Rüpke, and C.Y. Galerne, 2013, Modeling fluid flow in sedimentary basins with sill intrusions: Implications for hydrothermal venting and climate change: Geochemistry, Geophysics, Geosystems, 14, 5244-5262, doi: 10.1002/2013GC005012.

Jackson, C. A.-L., 2012, Seismic reflection imaging and controls on the preservation of ancient sill-fed magmatic vents: Journal of the Geological Society, 169, 503-506, doi: 10.1144/0016-76492011-147.

Jamtveit, B., H. Svensen, Y. Y. Podladchikov, and S. Planke, 2004, Hydrothermal vent complexes associated with sill intrusions in sedimentary basins: Physical Geology of High-Level Magmatic Systems, 234, 233-241, doi: 10 .1144/GSL.SP.2004.234.01.15.

Kennett, J., and L. Stott, 1991, Abrupt deep-sea warming, palaeoceanographic changes and benthic extinctions at the end: Nature, 353, 225-229, doi: 10.1038/353225a0.

Lecomte, I., P. L. Lavadera, I. Anell, S. J. Buckley, D. W. Schmid, and M. Heeremans, 2015, Ray-based seismic modeling of geologic models: Understanding and analyzing seismic images efficiently: Interpretation, 3, SAC71-SAC89, doi: 10.1190/INT-2015-0061.1.

Lecomte, I., P. L. Lavadera, C. Botter, I. Anell, S. J. Buckley, C. H. Eide, A. Grippa, V. Mascolo, and S. Kjoberg, 2016, 2(3)D convolution modelling of complex geological targets beyond 1D convolution: FB Special Topic, no. First Break 34, 64-72.

Magee, C., C. A.-L. Jackson, and N. Schofield, 2014, Diachronous sub-volcanic intrusion along deep-water margins: Insights from the Irish Rockall Basin: Basin Research, 26, 85-105, doi: 10.1111/bre.12044.

Miles, A., and J. Cartwright, 2010, Hybrid flow sills: A new mode of igneous sheet intrusion: Geology, 38, 343-346.

Mosar, J., E. A. Eide, P. T. Osmundsen, A. Sommaruga, and T. H. Torsvik, 2002, Greenland-Norway separation: A geodynamic model for the North Atlantic: Norwegian Journal of Geology, 82, 281-298.

Nermoen, A., O. Galland, E. Jettestuen, K. Fristad, Y. Podladchikov, H. Svensen, and A. Malthe-Sørenssen, 2010, Experimental and analytic modeling of piercement structures: Journal of Geophysical Research: Solid Earth, 115, 1-15, doi: 10.1029/2010JB007583.

Norris, R. D., and U. Röhl, 1999, Carbon cycling and chronology of climate warming during the Palaeocene/Eocene transition: Nature, 401, 775-778, doi: 10.1038/44545.

Passey, S. R., and D. W. Jolley, 2009, A revised lithostratigraphic nomenclature for the Palaeogene Faroe Islands Basalt group, NE Atlantic Ocean: Earth and Environmental Science Transactions of the Royal Society of Edinburgh 99, 127-158, doi: 10.1017/S1755691009008044.

Planke, S., T. Rasmussen, S. Rey, and R. Myklebust, 2005, Seismic characteristics and distribution of volcanic intrusions and hydrothermal vent complexes in the Vøring and Møre basins: Geological Society of London, Proceedings Geological Society, London, Petroleum Geology Conference series 6, 833-844.

Planke, S., H. Svensen, M. Hovland, D. A. Banks, and B. Jamtveit, 2003, Mud and fluid migration in active mud volcanoes in Azerbaijan: Geo-Marine Letters, 23, 258268. doi: 10.1007/s00367-003-0152-z.

Planke, S., H. Svensen, R. Myklebust, S. Bannister, B. Manton, and L. Lorenz, 2015, Geophysics and remote sensing: Advances in Volcanology, IAVCEI: Springer International Publishing.

Röhl, U., T. Bralower, R. Norris, and G. Wefer, 2000, New chronology for the late Paleocene thermal maximum and its environmental implications: Geology, 28, 927-930, doi: 10.1130/0091-7613(2000)28<927:ncftlp>2.0.co;2. 
Röhl, U., T. Westerhold, T. J. Bralower, and J. C. Zachos, 2007, On the duration of the Paleocene-Eocene thermal maximum (PETM): Geochemistry, Geophysics, Geosystems, 8, doi: 10.1029/2007GC001784.

Schmiedel, T., S. Kjoberg, S. Planke, C. Magee, O. Galland, N. Schofield, C. A.-L. Jackson, and D. A. Jerram, 2017, Mechanisms of overburden deformation associated with the emplacement of the Tulipan sill, mid-Norwegian margin: Interpretation, 5, 1-15, doi: 10.1190/INT2016-0155.1.

Schmitz, B., B. Peucker-Ehrenbrink, C. Heilmann-Clausen, G. Åberg, F. Asaro, and C.-T. A. Lee, 2004, Basaltic explosive volcanism, but no comet impact, at the Paleocene-Eocene boundary: High-resolution chemical and isotopic records from Egypt, Spain and Denmark: Earth and Planetary Science Letters, 225, 1-17, doi: 10.1016/j.epsl.2004.06.017.

Schofield, N., S. Holford, J. Millett, D. Brown, R. Jolley, S. Passey, D. Muirhead, C. Grove, C. Magee, J. Murray, M. Hole, A.-L. Jackson, and C. Stevenson, 2015, Regional magma plumbing and emplacement mechanisms of the Faroe-Shetland Sill Complex: Implications for magma transport and petroleum systems within sedimentary basins: Basin Research, 29, 41-63, doi: 10.1111/bre.12164.

Schofield, N, D. W. Jolley, S. Holford, S. G. Archer, D. Watson, A. J. Hartley, J. Howell, D. Muirhead, J. Underhill, and P. Green, 2017, Challenges of future exploration within the UK Rockhall Basin.

Schroot, B. M., and R. T. Schüttenhelm, 2003, Shallow gas and gas seepage: Expressions on seismic and otheracoustic data from the Netherlands North Sea: Journal of Geochemical Exploration, 78, 305-309, doi: 10 .1016/S0375-6742(03)00112-2.

Skogseid, J., T. Pedersen, O. Eldholm, and B. T. Larsen, 1992, Tectonism and magmatism during NE Atlantic continental break-up: The Vøring Margin: Geological Society, London, Special Publications, 68, 305-320.

Sluijs, A., S. Schouten, M. Pagani, M. Woltering, H. Brinkhuis, J. S. S. Damsté, G. R. Dickens, M. Huber, G.-J. Reichart, and R. Stein, 2006, Subtropical Arctic Ocean temperatures during the Palaeocene/Eocene thermal maximum: Nature, 441, 610-613, doi: 10.1038/nature04668.

Smallwood, J. R., and J. Maresh, 2002, The properties, morphology and distribution of igneous sills: Modelling, borehole data and 3D seismic from the Faroe-Shetland area, in D. W. Jolley, and B. R. Bell, eds., The North Atlantic Igneous Province: Stratigraphy, tectonic, volcanic and magmatic processes: Geological Society, London, Special Publications 197, 271-306.

Storey, M., R. A. Duncan, and C. C. Swisher, 2007, Paleocene-Eocene thermal maximum and the opening of the northeast Atlantic: Science, 316, 587-589, doi: 10.1126/ science. 1135274 .

Svensen, H., and B. Jamtveit, 2010, Metamorphic fluids and global environmental changes: Elements, 6, 179-182, doi: $10.2113 /$ gselements.6.3.179w.
Svensen, H., B. Jamtveit, S. Planke, and L. Chevallier, 2006, Structure and evolution of hydrothermal vent complexes in the Karoo Basin, South Africa: Journal of the Geological Society, 163, 671-682, doi: 10.1144/1144764905-037.

Svensen, H., S. Planke, L. Chevallier, A. Malthe-Sørenssen, F. Corfu, and B. Jamtveit, 2007, Hydrothermal venting of greenhouse gases triggering Early Jurassic global warming: Earth and Planetary Science Letters, 256, 554-566, doi: 10.1016/j.epsl.2007.02.013.

Svensen, H., F. Corfu, S. Polteau, Ø. Hammer, and S. Planke, 2012, Rapid magma emplacement in the Karoo Large Igneous Province: Earth and Planetary Science Letters, 325-326, 1-9, doi: 10.1016/j.epsl.2012.01.015.

Svensen, H., S. Planke, A. Malthe-Sørenssen, B. Jamtveit, R. Myklebust, T. R. Eidem, and S. S. Rey, 2004, Release of methane from a volcanic basin as a mechanism for initial Eocene global warming: Nature, 429, 542-545, doi: 10.1038/nature02566.

Svensen, H. H., S. Planke, B. Jamtveit, and T. Pedersen, 2003, Seep carbonate formation controlled by hydrothermal vent complexes: A case study from the Vøring Basin, the Norwegian Sea: Geo-Marine Letters, 23, 351358, doi: 10.1007/s00367-003-0141-2.

Wang, D., and M. Manga, 2015, Organic matter maturation in the contact aureole of an igneous sill as a tracer of hydrothermal convection: Journal of Geophysical Research: Solid Earth, 120, 4102-4112, doi: 10.1002/ 2015JB011877.

Westerhold, T., U. Röhl, H. K. McCarren, and J. C. Zachos, 2009 , Latest on the absolute age of the PaleoceneEocene thermal maximum (PETM): New insights from exact stratigraphic position of key ash layers +19 and-17: Earth and Planetary Science Letters 287, 412-419, doi: 10. 1016/j.epsl.2009.08.027.

Whitaker, S., 1986, Flow in porous media I: A theoretical derivation of Darcy's law: Transport in porous media, 1, 3-25, doi: 10.1007/BF01036523.

Zachos, J., M. Pagani, L. Sloan, E. Thomas, and K. Billups, 2001, Trends, rhythms, and aberrations in global climate 65 Ma to present: Science, 292, 686-693, doi: 10.1126/ science.1059412.

Zachos, J. C., R. G. Dickens, and R. E. Zeebe, 2008, An early Cenozoic perspective on greenhouse warming and carbon-cycle dynamics: Nature, 451, 279-283, doi: 10.1038/ nature06588.

Zhao, F., S. Wu, Q. Sun, M. Huuse, W. Li, and Z. Wang, 2014, Submarine volcanic mounds in the Pearl River Mouth Basin, northern South China Sea: Marine Geology, 355, 162-172, doi: 10.1016/j.margeo.2014.05.018.

Biographies and photographs of authors are not available. 